Linköping Studies in Science and Technology, Dissertation No. 1725

\title{
On High-Temperature Behaviours of Heat Resistant Austenitic Alloys
}

\author{
Mattias Calmunger
}

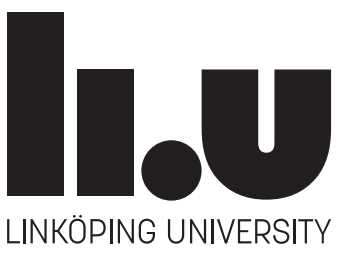

\author{
Division of Engineering Materials \\ Department of Management and Engineering \\ Linköping University, SE-581 83, Linköping, Sweden \\ http://www.liu.se
}

Linköping, November 2015 
Opponent: Prof. Dr.-Ing. Hans-Jürgen Christ, Universität Siegen, Institut für Werkstofftechnik, Germany.

Date: 10:15, December 21, 2015

Room: ACAS, Linköping University

Cover:

Fracture surface from impact tested

austenitic alloy after 10000 hours ageing at $650{ }^{\circ} \mathrm{C}$.

Printed by:

LiU-Tryck, Linköping, Sweden, 2015

ISBN 978-91-7685-896-7

ISSN 0345-7524

Distributed by:

Linköping University

Department of Management and Engineering

SE-581 83, Linköping, Sweden

(C) 2015 Mattias Calmunger

This document was prepared with $\mathrm{HT}_{\mathrm{E}} \mathrm{X}$, November 13, 2015 


\section{Abstract}

Advanced heat resistant materials are important to achieve the transition to long term sustainable power generation. The global increase in energy consumption and the global warming from greenhouse gas emissions create the need for more sustainable power generation processes. Biomass-fired power plants with higher efficiency could generate more power but also reduce the emission of greenhouse gases, e.g. $\mathrm{CO}_{2}$. Biomass is the largest global contributor to renewable energy and offers no net contribution of $\mathrm{CO}_{2}$ to the atmosphere. To obtain greater efficiency of power plants, one option is to increase the temperature and the pressure in the boiler section of the power plant. Raised temperature and pressure increase the demands of the operating materials of the future high-efficient biomass-fired power plants. This requires improved properties, such as higher yield strength, creep strength and high-temperature corrosion resistance, as well as structural integrity and safety. Also, the number of start-and-stop cycles will increase, leading to demands on increased material performance under cyclic loading, both from thermal and mechanical loads.

Heat resistant austenitic alloys, such as austenitic stainless steels and nickelbased alloys, possess excellent mechanical and chemical properties at the elevated temperatures and cyclic loading conditions of today's biomass-fired power plants. Today, some austenitic stainless steels are design to withstand temperatures up to $650{ }^{\circ} \mathrm{C}$ in tough environments. Nickel-based alloys are designed to withstand even higher temperatures. Austenitic stainless steels are more cost effective than nickel-based alloys due to a lower amount of expensive alloying elements. However, the performance of austenitic stainless steels at the elevated temperatures of future operation conditions in biomassfired power plants is not yet fully understood.

This thesis presents research on the influence of long term high-temperature ageing on mechanical properties, the influence of very slow deformation rates at high-temperature on deformation, damage and fracture, and the influence 
of high-temperature environment and cyclic operation conditions on the material behaviour. The research has been conducted on several commercial heat resistant austenitic alloys. Mechanical testing, such as impact toughness tests, uniaxial tensile tests at elevated temperatures using various strain rates and creep-fatigue interaction tests, has been performed. Also, thermal testing such as long term ageing and thermal cycling in a water vapour environment has been performed. The mechanical and thermal testing have been followed by subsequent studies of the microstructure, using scanning electron microscopy, to investigate the deformation, damage and fracture mechanisms as well as the precipitation and corrosion behaviours.

Results shows that long term ageing (up to 10000 hours) at high temperatures (up to $700{ }^{\circ} \mathrm{C}$ ) leads to the precipitation of intermetallic phases. These intermetallic phases are brittle at room temperature and become detrimental for the impact toughness of some of the austenitic stainless steels. The dominant deformation mechanisms during uni-axial tensile testing at elevated temperatures using moderate strain rates are dislocation driven planar slip and localised slip bands as well as deformation twinning. When the strain rate is decreased, these deformation mechanisms are accompanied with time dependent deformation and recovery mechanisms, such as dynamic recovery and dynamic recrystallisation. The creep-fatigue interaction behaviour of an austenitic stainless steel shows that dwell time causes a larger plastic strain range. The results also show that dwell time gives shorter life at a lower strain range, but has none or small effect on the life at a higher strain range. Thermal cyclic testing in a water vapour environment of an austenitic stainless steel shows the results of the detrimental chromium vaporisation, causing both outward oxide growth of a non-protective iron rich oxide and inward oxide scale growth of spinel oxides, consuming the bulk material.

Finally, this research results in an increased knowledge of the structural, mechanical and chemical behaviour as well as a deeper understanding of the deformation, damage and fracture mechanisms that occur in heat resistant austenitic alloys at high-temperature environments. It is believed that in the long term, this can contribute to material development achieving the transition to more sustainable power generation in biomass-fired power plants. 
随着全球能源消耗的持续增长以及因温室气体排放所造成的气候不断变暖, 发展更为 高效, 可持续的新能源电力系统已经刻不容缓, 而先进耐热材料的研究和使用对于推 动能源电力产业的升级至关重要。生物燃料被视为新一代的可再生绿色能源。利用生 物燃料发电, 可在大幅提升发电量和发电效率的同时, 显著减少二氧化碳等温室气体 的排放。与此同时, 为了获得更高的发电效率, 还需进一步提高燃烧室的工作温度和 工作压力, 但这对所使用材料的高温力学性能 (断裂强度, 蠕变强度), 抗腐蚀性能 以及组织结构的完整性和使用的安全性提出了更为严格的要求。此外, 发电机组日益 频繁的交替运行也要求材料在交变温度载荷和应力载荷下具备更为出色的抗疲劳性能。

奥氏体耐热合金，如奥氏体不锈钢和镍基合金，在高温和交变载荷条件下具有优异的 力学性能和化学稳定性, 因而被大量使用于现代生物燃料发电机组中。奥氏体不锈钢 在经过特殊设计后能够在高达 650 摄氏度的严酷环境中工作，而镍基合金则可被应用 于更高的工作温度。相比于镍基合金，奥氏体不锈钢较少使用昂贵的合金元素，性价 比更高。但未来随着生物燃料发电机组运行温度和压力的不断提高, 其在更加严苛环 境下服役时的表现还有待进一步研究。

本篇论文主要涵盖了以下几方面的研究工作：1）长时间高温时效对奥氏体耐热合金力 学性能的影响, 2) 高温及低形变速率下, 奥氏体耐热合金的形变, 损伤和断裂行为, 3）高温环境和热循环对奥氏体耐热合金氧化, 腐蚀行为的影响。本研究选取了几种市 场上已经流通的奥氏体耐热合金, 进行了包括材料冲击韧性, 高温及不同应变速率下 的单轴拉伸, 蠕变和疲劳载荷交互作用在内的力学性能测试, 以及长时间高温时效和 湿润环境下的热循环氧化在内的热力学性能测试。随后, 本研究利用扫描电子显微镜, 对测试后样品的微观组织结构进行了研究和观察, 以探索材料的变形, 损伤, 断裂机 制以及析出, 氧化和腐蚀行为。

研究发现高温下长时间时效会导致金属间化合物在合金中析出。这类金属间化合物在 室温下脆性较强，因而会降低一些奥氏体耐热合金的室温冲击韧性。高温单轴拉伸实 验结果表明当应变速率适中时, 合金的主要形变机制为位错的平面滑移, 局部滑移带 和形变孪晶, 而随着应变速率的降低, 合金形变时会伴有动态回复和再结晶的发生。 在蠕变和疲劳载荷交互作用下, 奥氏体耐热合金的塑性应变有所增加。并且, 在㽻劳 测试中施加一定的驻留时间会降低合金的疲劳寿命，但在高应变疲劳测试中，该现象 并不显著。此外, 研究还发现在湿润环境中, 交变热力场导致合金表面氧化铬保护层 气化, 非保护性富铁氧化物和 Spinel 氧化层形成, 进而合金被进一步氧化消耗。

以上的研究工作和成果有助于进一步认识奥氏体耐热合金高温下的组织结构, 力学性 能和化学稳定性, 并且对该类合金高温下的形变, 损伤和断裂机制形成更为深入的理 解。长远来看, 相信这些结果会对奥氏体耐热合金的发展以及日后其在更高效, 可持 续新型生物燃料发电机组中的应用产生卓越的贡献。 



\section{Populärvetenskaplig sammanfattning på svenska}

Avancerade värmebeständiga material är viktiga för att klara övergången till långsiktig, hållbar energiproduktion. Den globala ökningen av energiförbrukningen och den globala uppvärmningen från utsläpp av växthusgaser skapar ett behov av mer hållbara energiproduktionsprocesser. Biobränsleeldade kraftverk med högre effektivitet skulle kunna generera mer energi, men också minska utsläppen av växthusgaser, t.ex. $\mathrm{CO}_{2}$. För att erhålla effektivare kraftverk är ett alternativ att öka temperaturen och trycket i förbränningsanläggningen. Förhöjda temperaturer och tryck samt val av nya bränslen ökar dock kraven på de material som ska användas i framtidens högeffektiva biobränsleeldade kraftverk. Detta kräver förbättrade egenskaper, såsom högre sträckgräns, utmattningshållfasthet, kryphållfasthet och högtemperaturkorrosionsbeständighet samt strukturell integritet och säkerhet. Detta innebär att materialen ska tåla mer påkänningar under längre tid.

Idag är austenitiska rostfria stål konstruerade för att tåla temperaturer upp till $650{ }^{\circ} \mathrm{C}$ i tuffa miljöer. Nickelbaserade legeringar, där nickel ersätter järn, är avsedda att tåla ännu högre temperaturer i tuffa miljöer. Austenitiska rostfria stål är mer kostnadseffektiva än nickelbaserade legeringar, detta på grund av en lägre mängd av dyra legeringselement. Dock är det ännu inte helt klarlagt hur austenitiska rostfria stål klarar de förhöjda temperaturer som de framtida driftsförhållandena innebär.

Denna avhandling presenterar forskning om hur materialens egenskaper påverkas av höga temperaturer under längre tid, hur de samtidigt påverkas av mycket långsam deformation, samt påverkan av cykliska driftsförhållanden vid hög temperatur. Mekanisk provning har utförts, såsom slagseghetstester, dragprovning med olika deformationshastigheter samt kombinerade hålltidsoch utmattningstester. Dessutom har termisk provning såsom långtidsåldring och termisk cykling i fuktig miljö vid höga temperaturer utförts. 
Resultaten från de termiska och mekaniska experimenten visar att långtidsåldring (upp till 10000 timmar) vid höga temperaturer (upp till $700{ }^{\circ} \mathrm{C}$ ) leder till uppkomsten av spröda intermetalliska faser i vissa austenitiska rostfria stål som påverkar livslängden hos kraftverken negativt. Ett annat exempel är att livslängden hos austenitiska rostfritt stål påverkas olika av hålltider under utmattningsprovning beroende på töjningsomfång. Hålltid vid maximallast får en negativ effekt på livslängden vid mindre töjningsomfång, men har ingen eller liten effekt vid större töjningsomfång.

Slutligen har denna forskning resulterat i en ökad kunskap om de strukturella, mekaniska och kemiska beteenden samt djupare förståelse av deformations, skade- och brottmekanismer som förekommer i värmebeständiga austenitiska legeringar vid höga temperaturer. På lång sikt kan detta bidra till den materialutveckling som krävs för att klara övergången till en mer hållbar energiproduktion. 


\section{Acknowledgement}

This research has been financially supported by AB Sandvik Materials Technology in Sandviken, Sweden, and the Swedish Energy Agency through the Research Consortium of Materials Technology for Thermal Energy Processes, Grant No. KME-501 and KME-701. They are all greatly acknowledged. Sandvik Heating Technology AB in Hallstahammar, Sweden, is also acknowledged for their financial support through KME-701.

Agora Materiae and the Strategic Faculty Grant AFM (SFO-MAT-LiU \#200900971) at Linköping University are also acknowledged.

I would like to express my gratitude to my main supervisor Sten Johansson, for the opportunity to work with interesting projects in a stimulating environment. His guidance has been very valuable and our discussions always resulted in improvements of the work. I especially appreciate the freedom he has given me to follow my ideas.

Further thanks goes to my co-supervisors Guocai Chai and Johan Moverare for their support and encouragement during my time as a PhD student. I am very glad that I have had the possibility to work with these two very knowledgeable researchers and I am looking forward to continue our collaboration in the future.

Both former and present colleagues at the division of Engineering Materials deserve appreciation for fruitful scientific discussions and creating an enjoyable working environment. I want thank $\mathrm{Ru}$ Lin Peng for introducing me to the world of in-situ tensile testing and analysis. Further, I would like to thank our administrator at the division, Ingmari Hallkvist, for always being helpful. The translation of the abstract to Chinese by Zhe Chen is greatly appreciated. The technical support from Annethe Billenius, Patrik Härnman, Per Johansson and Peter Karlsson are greatly acknowledged. I also want to mention the great support from Sören Kahl, discussing the carrier as a researcher, and Viktor Norman for numerous discussions on physics and 
mathematics and the help with data analysis in Matlab. A special thank goes to Robert Eriksson for co-authoring two of the included papers, the thermodynamic modelling and the proof reading of this thesis.

In addition, a collective acknowledgement goes to my colleagues at Sandvik Materials Technology, especially to Jan Högberg for his valuable work within the projects and the knowledge he has provided, Jerry Lindqvist for his help and assistance with microscopy, and Dan-Erik Gräll and Håkan Nylén for their assistance with mechanical testing.

Finally, I would like to thank my family and friends for all their support and encouragement. My deepest gratitude goes to my beloved wife Linda and my dear children Agust and Thea, for all their patience, support and for reminding me what is the most valuable in life. Without their love and support this book had never been written.

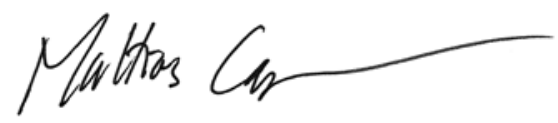

Mattias Calmunger

Linköping, October 2015 


\section{List of Papers}

In this thesis, the following papers have been included:

I. M. Calmunger, G. Chai, S. Johansson and J. Moverare, Long term high-temperature environmental effect on impact toughness in austenitic alloys, Key Engineering Materials, vol. 627, pp. 205208, 2015

I performed the microstructure investigations and was the main contributor of the manuscript writing. The ageing and mechanical testing were performed at AB Sandvik Materials Technology in Sandviken, Sweden.

II. M. Calmunger, G. Chai, S. Johansson and J. Moverare, Damage and fracture behaviours in aged austenitic materials during high temperature slow strain rate testing, Key Engineering Materials, vol. 592-593, pp. 590-593, 2014.

I performed the ageing, the mechanical testing, the microstructure investigations and was the main contributor of the manuscript writing.

II. M. Calmunger, R. L. Peng, G. Chai, S. Johansson and J. Moverare, Advanced microstructure studies of an austenitic material using EBSD in elevated temperature in-situ tensile testing in SEM, Key Engineering Materials, vol. 592-593, pp. 497-500, 2014.

I performed in-situ mechanical testing along with the microstructure investigations and was the main contributor of the manuscript writing.

IV. M. Calmunger, G. Chai, S. Johansson and J. Moverare, Mechanical behaviours of Alloy 617 with varied strain rate at high temperatures, Materials Science Forum, vol. 783-786, pp. 1182-1187, 2014.

I performed the mechanical testing and was the main contributor of the 
manuscript writing. The microstructure investigations was performed at AB Sandvik Materials Technology in Sandviken, Sweden.

V. M. Calmunger, G. Chai, S. Johansson and J. Moverare, Deformation behaviour in advanced heat resistant materials during slow strain rate testing at elevated temperature, Theoretical \& Applied Mechanics Letters, vol. 4, pp. 041004-1-041004-6, 2014.

I performed the mechanical testing, the microstructure investigations and was the main contributor of the manuscript writing.

VI. M. Calmunger, G. Chai, R. Eriksson, S. Johansson and J. J. Moverare, Characterisation of austenitic stainless steels deformed at elevated temperature, submitted to Materials Characterization.

I performed the microstructure investigations and was the main contributor of the manuscript writing. The mechanical testing and some additional microstructure investigation were performed at AB Sandvik Materials Technology in Sandviken, Sweden.

VII. M. Calmunger, J. J. Moverare, S. Johansson and G. Chai, Characterisation of creep deformation during slow strain rate tensile testing, in manuscript.

I performed the mechanical testing, the microstructure investigations and was the main contributor of the manuscript writing. The modelling was performed by Johan J. Moverare.

VIII. M. Calmunger, G. Chai, S. Johansson and J. Moverare, Creep and fatigue interaction behavior in Sanicro 25 heat resistant austenitic stainless steel, 7th International Conference on Creep, Fatigue and Creep-Fatigue Interaction, Kalpakkam, India, 2016. Also submitted to Transactions of the Indian Institute of Metals.

I performed the mechanical testing, the microstructure investigations and was the main contributor of the manuscript writing. Some additional microstructure investigation was performed at AB Sandvik Materials Technology in Sandviken, Sweden.

IX M. Calmunger, G. Chai, S. Johansson and J. J. Moverare, Surface phase transformation in austenitic stainless steel induced by cyclic oxidation in humidified air, Corrosion Science, vol. 100, pp. 524-534, 2015.

I performed the cyclic thermal testing, the microstructure investigations 
and was the main contributor of the manuscript writing. Robert Eriksson did the modelling part and Biplab Paul (from the Department of Physics) did the grazing incidence X-ray diffraction measurement.

Papers not included in this thesis:

X. S. Kahl, R. L. Peng, M. Calmunger, Björn Olsson and S. Johansson, In-situ EBSD during tensile test of aluminum AA3003 sheet, Micron, vol. 58, pp. 15-24, 2014.

XI. M. Calmunger, G. Chai, S. Johansson and J. Moverare, Influence of deformation rate on mechanical response of an AISI 316L austenitic stainless steel, Advanced Materials Research, vol. 922, pp. 49-54, 2014.

XII. M. Calmunger, G. Chai, S. Johansson and J. Moverare, Influence of high temperature ageing on the toughness of advanced heat resistant materials, Presented at ICF13, Beijing (China), 2013.

XIII. M. Calmunger, G. Chai, S. Johansson and J. Moverare, Damage and fracture behaviours in advanced heat resistant materials during slow strain rate test at high temperature, Presented at ICF13, Beijing (China), 2013.

IVX. M. Lundberg, M. Calmunger and R. L. Peng, In-situ SEM/EBSD study of deformation and fracture behaviour of flake cast iron, Presented at ICF13, Beijing (China), 2013.

VX. M. Calmunger, G. Chai, S. Johansson and J. Moverare, Influence of dynamic strain ageing on damage in austenitic stainless steels, Presented at ECF19, Kazan (Russia), 2012. 



\section{Contents}

$\begin{array}{ll}\text { Abstract } & \text { iii }\end{array}$

Chinese abstract $\quad$ v

Populärvetenskaplig sammanfattning på svenska vii

Acknowledgement $\quad$ ix

List of Papers $\quad$ xi

Contents $\quad$ Xv

Abbreviation $\quad$ xix

Part I Background and Theory xxi

1 Introduction $\quad 1$

1.1 Challenges for a more sustainable power generation . . . . . . 2

1.2 Introduction and aims of the research project . . . . . . . . 3

1.3 Outline of the thesis . . . . . . . . . . . . . . . 4

2 Austenitic alloys $\quad 7$

2.1 Austenitic stainless steels . . . . . . . . . . . . . . 8

2.1.1 Main alloying elements in austenitic stainless steels . . 8

2.1.2 Influence of alloying elements on stacking-fault energy . 9

2.1.3 Precipitation of austenitic stainless steels . . . . . . . . 10

2.2 Nickel-based alloys . . . . . . . . . . . . . . . . . . . . . . . . 11

2.2.1 Main alloying elements in nickel-based alloys . . . . . . 11

2.2.2 Precipitation of nickel-based alloys . . . . . . . . 12 
3 Microstructural mechanisms and phenomena 13

3.1 Deformation mechanisms . . . . . . . . . . . . . . . . . . . . . 14

3.1.1 Dislocation movement . . . . . . . . . . . . . 14

3.1 .2 Twinning ....................... 15

3.2 Time dependent deformation mechanisms . . . . . . . . . . . . 16

3.2 .1 Creep . . . . . . . . . . . . . . . 16

3.2.2 Creep-fatigue interaction . . . . . . . . . . . . . 16

3.3 Softening phenomena . . . . . . . . . . . . . . 17

3.3 .1 Dynamic recovery . . . . . . . . . . . . . . . . . 17

3.3.2 Dynamic recrystallization . . . . . . . . . . . . . . 18

3.4 Dynamic strain ageing . . . . . . . . . . . . . . . . . 18

3.5 Oxidation . . . . . . . . . . . . . . . . . . 19

4 Experimental methods 21

4.1 Material ...................... . . 22

4.2 Ageing . . . . . . . . . . . . . . . . . . . . . . . . . . . . . . . . . . . .

4.3 Impact toughness testing . . . . . . . . . . . . . . . . . 24

4.4 Tensile deformation . . . . . . . . . . . . . . . . . . . . . . 24

4.5 Creep-fatigue interaction testing . . . . . . . . . . . . . 26

4.6 Thermal cycling in water vapour environment . . . . . . . . . 26

4.7 Microscopy . . . . . . . . . . . . . . . . . . . . . . . 27

4.7.1 Scanning electron microscopy . . . . . . . . . . . . . 27

4.7.2 Specimen preparation . . . . . . . . . . . . . . 30

$5 \quad$ Review of appended papers $\quad 31$

$\begin{array}{lll}6 & \text { Conclusions } & 37\end{array}$

$\begin{array}{lll}7 & \text { Outlook } & 41\end{array}$

Bibliography 43

$\begin{array}{lll}\text { Part II Papers Included } & 57\end{array}$

Paper I: Long term high-temperature environmental effect on $\begin{array}{ll}\text { impact toughness in austenitic alloys } & 61\end{array}$

Paper II: Damage and fracture behaviours in aged austenitic materials during high-temperature slow strain rate testing $\quad 67$ xvi 
Paper III: Advanced microstructure studies of an austenitic material using EBSD in elevated temperature in-situ tensile testing in SEM

Paper IV: Mechanical behaviours of Alloy 617 with varied strain rate at high temperatures

Paper V: Deformation behaviour in advanced heat resistant materials during slow strain rate testing at elevated temperature

Paper VI: Characterisation of austenitic stainless steels deformed at elevated temperature

Paper VII: Characterisation of creep deformation during slow strain rate tensile testing

Paper VIII: Creep and fatigue interaction behavior in Sanicro 25 heat resistant austenitic stainless steel

Paper IX: Surface phase transformation in austenitic stainless steel induced by cyclic oxidation in humidified air 



\title{
Abbreviation
}

\author{
AUSC advanced ultra-super critical \\ BCC body-centred cubic \\ BCT body-centred tetragonal \\ BSE backscattered electron \\ DB deformation band \\ DRV dynamic recovery \\ DRX dynamic recrystallization \\ DSA dynamic strain ageing \\ EBSD electron backscatter diffraction \\ ECCI electron channeling contrast imaging \\ EDS energy-dispersive system \\ FCC face-centred cubic \\ FEG field emission gun \\ FIB focused ion beam \\ GAM grain average misorientation \\ GB grain boundary \\ IPF inverse pole figure \\ LAGB low angle grain boundary \\ $\mathrm{LCF}$ low cycle fatigue \\ PLC Portevin-Le Châtelier \\ RT room temperature \\ SB slip band \\ SEM scanning electron microscopy \\ SF Schmid factor \\ SFE stacking-fault energy \\ SSRT slow strain rate tensile testing \\ TB twin boundary \\ TWIP twinning induced plasticity
}





\section{Part I}

\section{Background and Theory}





\section{1 \\ Introduction}

This chapter introduces the background and the aims of the research that has been conducted within the work of this PhD thesis. This chapter also addresses the research program of which the conducted research is a smaller part, to put the thesis in a wider context. 


\subsection{Challenges for a more sustainable power generation}

Biomass is the largest global contributor to renewable energy and its use has a great potential to expand for production of heat and electricity [1-5]. Biomass is the collective label of any organic matter which is derived from plants. There are plant biomass and animal biomass, since also animals use plants as food. The energy from the sun is converted by plants, through the process of photosynthesis, into chemical energy. During the process of photosynthesis, $\mathrm{CO}_{2}$ is consumed [4]. Therefore, biomass is considered a sustainable fuel because it gives no net increase of $\mathrm{CO}_{2}$ to the atmosphere and it can be considered endless [1-5]. However, the global increase in energy consumption and the increase in emissions of greenhouse gases (e.g. $\mathrm{CO}_{2}$ ), causing global warming, create needs for both an increase in energy production and a reduction of greenhouse gas emission $[1,3,6,7]$. One way to accomplish both needs is to increase the efficiency of biomass-fired power plants which could be reached by increasing temperature and pressure in the boiler sections $[2,5,8,9]$. Another option to increase the efficiency of biomass-fired power plants is to change the design of the power plant [5]; however, this option is not within the scope of this thesis. The materials used for future biomass-fired power plants with higher efficiency are required to display improved properties as higher yield strength, fatigue strength, creep strength and high-temperature corrosion resistance [9-13]. Also, the number of start-and-stop cycles will increase, leading to requirements on increased material performance under cyclic loading, both from thermal and mechanical loads $[2,14]$.

Heat resistant austenitic alloys, such as austenitic stainless steels and nickel-based alloys, possess excellent mechanical and chemical properties at the elevated temperatures and the cyclic loading conditions of today's biomass-fired power plants. These austenitic alloys are often used in the boiler section, as for instance as tubes in superheaters [2, 5, 8, 9]. Today some austenitic stainless steels are designed to withstand temperatures up to $650{ }^{\circ} \mathrm{C}$ in tough environments $[9,11,15]$. Nickel-based alloys are designed to withstand even higher temperatures in tough environments $[11,16]$. However, austenitic stainless steels are more cost effective than nickel-based alloys due to a lower amount of expensive alloying elements. The performance of austenitic stainless steels at the elevated temperatures of future operation conditions in biomass-fired power plants is not yet fully understood. 


\subsection{Introduction and aims of the research project}

This thesis consists of research conducted in two projects: Long term high temperature behaviour of advanced heat resistant materials, denoted KME501, and the succeeding project Influence of high-temperature environments on the mechanical behaviours of high-temperature austenitic stainless steels, denoted KME-701. The research projects started with a M.Sc. thesis work, Effect of temperature on mechanical response of austenitic materials [17] in the summer of 2011. The work continued within the KME-501 project that ended in the beginning of 2014, and the current project KME-701 started after the summer 2014. The projects are carried out in a strong collaboration between Linköping University and AB Sandvik Materials Technology in Sandviken, Sweden. The projects are financed through the Research Consortium of Materials Technology for Thermal Energy Processes (KME), grant no. KME-501 and KME 701. The purpose of the research within KME is to make thermal energy processes more effective and is financially supported by both industries (60\%) and the Swedish Energy Agency (40\%).

The general goals of KME's program periods 2010-2013 and 2014-2017 state that $[18]$ :

"The program will contribute to the conversion to a sustainable energy system by development of more effective energy processes."

and

"The programme's overall goal is to help to make a transition to an energy system which is sustainable in the long term thanks to materials and process technology development for thermal energy processes based on renewable fuels and waste."

One way to fulfil the general goals is to increase the efficiency of biomass power plants by raising the temperature and pressure in the boiler section, as described in Chapter 1.1. However, to obtain a long term sustainable energy system, the use of materials must be optimised in the meaning of using less expensive materials and with low environmental impact. It is this combination that austenitic stainless steels possess compared to other heat resistant materials, such as nickel-based alloys. Since austenitic stainless 
steels are not designed to operate in temperatures above $650{ }^{\circ} \mathrm{C}$, the hightemperature behaviour at temperatures above $650{ }^{\circ} \mathrm{C}$ needs to be studied for further material development.

The aims of this $\mathrm{PhD}$ thesis will help to fulfil the general goals of the KME programs by adding useful knowledge for future material development concerning:

1. The influence of long term high-temperature ageing on mechanical properties.

2. The influence of very slow deformation rates at high-temperature on deformation, damage and fracture.

3. The influence of high-temperature environment and cyclic operation conditions on the material behaviour.

Each one of these aims are treated in one or several of the papers included in Part II.

\subsection{Outline of the thesis}

This thesis consists of several introductory chapters, Part I, and nine academic papers, Part II. The introductory chapters are based upon the licentiate thesis High-Temperature Behaviour of Austenitic Alloys - Influence of Temperature and strain rate on Mechanical Properties and Microstructural Development [19], which was presented in November 2013. However, since then, new work has been performed which is presented in this $\mathrm{PhD}$ thesis.

Part I - Background and Theory, consists of seven chapters. The aim of Part I is to give an introduction and present the background of this research area as well as interconnect the included papers in Part II with each other. In Chapter 1, the reader is introduced to the research project which the work conducted within this $\mathrm{PhD}$ thesis is a part of and the aims of this $\mathrm{PhD}$ thesis are also presented. Chapter 2 and 3, give a general description of austenitic stainless steels, nickel-based alloys and the microstructural mechanisms and phenomena central in this PhD thesis; they are mainly based on Ref.[19]. Chapter 4 presents the experimental methods that have been used and is mainly based on Ref.[19]. Chapter 5 provides a review of the appended papers. Chapter 6 presents the conclusions of this work and Chapter 7 gives a outlook of possible future work based on this $\mathrm{PhD}$ thesis. 


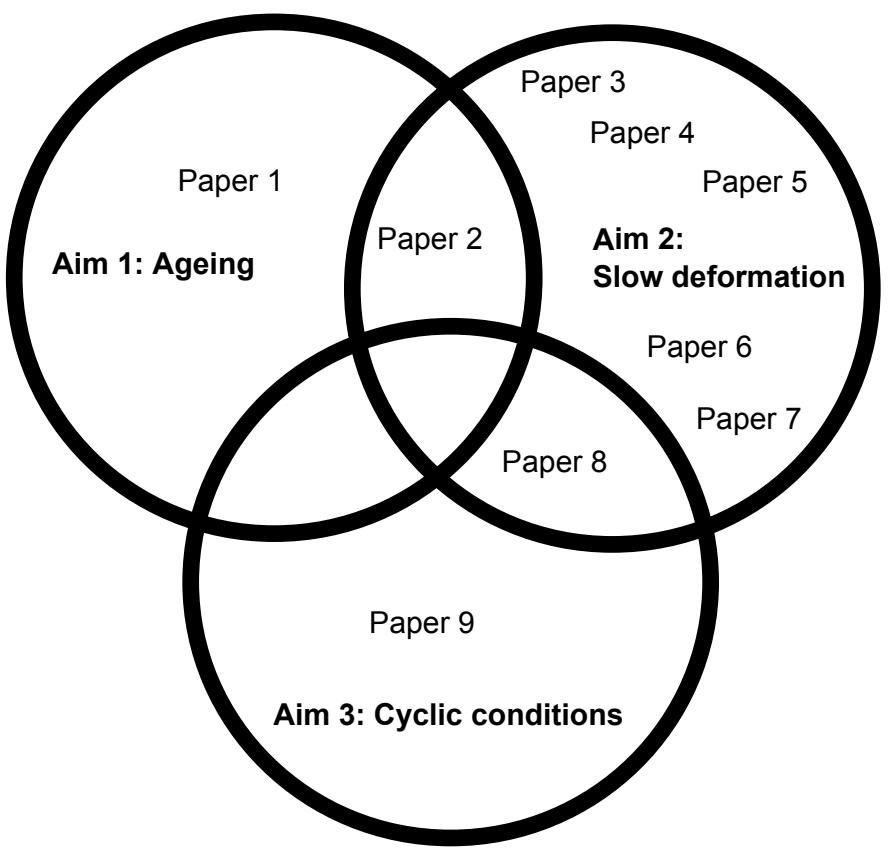

Figure 1: The connection between the aims and each paper included.

Part II - Papers Included, collects nine papers describing the main research that has been conducted in the projects. Papers $I-I V$ are international conference articles that have been peer-reviewed and published in periodicals. Paper VIII is accepted for presentation on an international conference and will appear in the proceedings after peer-review as well as submitted and is under review at an international journal. Paper $V$ and IX have been published in peer-reviewed international journals. Paper VI has been submitted to an international journal and is under review. Paper VII is in manuscript form. The papers are not arranged in chronological order; instead, they are organised by the content and how they relate to the aims described in Chapter 1.2. Fig. 1 show the connection between the aims and each paper. 



\section{Austenitic alloys}

This chapter provides general information about the heat resistant austenitic alloys addressed in this thesis: austenitic stainless steels and nickel-based alloys. This review will cover some of the important alloying elements as well as precipitation. The review will concentrate on austenitic stainless steels. 


\subsection{Austenitic stainless steels}

The main feature of stainless steels is their resistance to corrosion. They also possess high ductility and toughness over a wide range of temperatures and exhibit excellent high-temperature oxidation resistance [9, 11, 20-23]. Stainless steels can be divided into five grades: ferritic, austenitic, martensitic, dual and multiphase (often referred to duplex), and precipitation hardened. Four of them are based on the characteristic crystallographic structure: ferritic, austenitic, martensitic and duplex phase. The fifth grade, precipitation hardened steels, is based on the type of heat treatment used rather than crystallographic structure [20-23]. Since this thesis only considers the chromium-nickel alloyed austenitic stainless steel, the other grades will not be covered in the review.

Austenitic stainless steels have a face-centred cubic (FCC) crystallographic structure, denoted $\gamma$. They are the most commonly used and the grade containing the largest number of alloys of the stainless steel grades. Austenitic stainless steels possess great corrosion resistance, good creep resistance and excellent ductility, formability and toughness [13, 20-22, 24]. These materials exhibit no ductile to brittle transition temperature, except for austenitic stainless steels with very high content of nitrogen at low temperatures [25]. In addition, they cannot be hardened by heat treatment, but significantly hardened by cold work. Austenitic stainless steels have relatively low yield strength but high work hardening rate compared to other stainless steel grades $[20,22,26]$. The alloys typically contain $16-26$ wt.\% Cr, 8-25 wt.\% $\mathrm{Ni}$ and 0-6wt.\% Mo, and are fully austenitic from well below RT to melting temperature $[20,22,23]$. These alloys are non-ferromagnetic, due to their crystallographic structure, and have greater heat capacity and thermal expansion, but lower thermal conductivity than other stainless steel grades $[20]$.

\subsubsection{Main alloying elements in austenitic stainless steels}

Austenitic stainless steels are iron-based and the main alloying elements in these materials are chromium, nickel, manganese, molybdenum, titanium, niobium, carbon and nitrogen $[13,20]$.

Chromium is added mainly to obtain corrosion resistance; it reacts rapidly with oxygen creating a protective layer of chromium oxide on the surface. If the amount of chromium is $12 \mathrm{wt} . \%$ or more, the oxide layer will self-repair if it gets damaged, because of the rapid reaction between chromium and oxygen $[20]$.

Nickel stabilises the FCC structure in iron. Nickel increases the size of the 
austenitic field, while nearly eliminating the body-centred cubic (BCC) ferrite structure from the iron-chromium-carbon alloys. Together with chromium, it produces high-temperature strength and scaling resistance.

Manganese stabilises austenite and can be used to replace nickel. Manganese improves the solubility of nitrogen.

Molybdenum improves both the local and the general corrosion resistance. Molybdenum is a ferrite stabiliser and must therefore be balanced with austenitic stabilisers to maintain the austenitic structure. It improves the creep properties $[13,20]$.

Titanium reduces intergranular corrosion if the carbon content is high. Titanium reacts more easily with carbon than chromium does, thus, titanium carbides are formed in preference to chromium carbides and localised reduction of chromium is prevented. It also greatly improves the creep strength [13].

Niobium creates carbides more easily than chromium and is therefore used for intergranular corrosion resistance [20]. A too great amount niobium may reduce the creep strength $[13,24]$.

Carbon additions stabilise the austenitic phase, but has a negative effect on corrosion resistance due to the formation of chromium carbides. If the carbon content is below about $0.03 \mathrm{wt} . \%$, the carbides do not form and the steel is virtually all austenitic at room temperature [20].

Nitrogen addition stabilises the austenitic phase and strengthens the material through solid solution hardening [20, 27], leading to enhanced creep life and low temperature yield strength. However, a too great amount of nitrogen will reduce the creep life of austenitic stainless steels [13].

\subsubsection{Influence of alloying elements on stacking-fault energy}

The stacking-fault energy (SFE) in austenitic stainless steels is influenced by the alloying elements $[28,29]$. Chromium decreases the SFE with increasing content in austenitic stainless steels, at least within the range of 10-26 at.\% chromium. Opposite to chromium, nickel increases the SFE in austenitic stainless steels, at least within the range of 8-20 at.\% nickel [29]. The influence of cobalt, manganese and niobium on the SFE in austenitic stainless steels depends on the amount of nickel. Cobalt decreases the SFE and the decrease is stronger in alloys with high nickel content. Manganese decreases the SFE in alloys with $<16$ at.\% nickel content. Niobium strongly increases the SFE in alloys with low nickel content, while the effect is considerable weaker when increasing the nickel content [28]. The SFE influences deformation mechanisms as twinning and dislocation movement; twinning and dislocation mechanisms are further explained in section 3.1. 


\subsubsection{Precipitation of austenitic stainless steels}

Austenitic stainless steels containing $18 \mathrm{wt} . \%$ chromium and $12 \mathrm{wt} . \%$ nickel should be fully austenitic at high temperatures. However, the addition of alloying elements may result in precipitation of secondary phases, such as various kinds of carbides, nitrides and intermetallic phases. These precipitates may not be desirable since they can affect mechanical and corrosion properties. Their appearances depend on the chemical compositions [13, 20, 23]. Only the most common precipitates in austenitic stainless steels will be considered in this section.

Carbides and nitrides

$M_{23} C_{6}$ is a carbide with FCC structure, usually containing chromium as the main metallic element $(\mathrm{M})$, but nickel, molybdenum and iron can substitute $[13,20,30]$. It nucleates very easily and therefore appears early in the precipitation process; it has been found after only $30 \mathrm{~min}$ at $750{ }^{\circ} \mathrm{C}$ in an austenitic stainless steel [31]. It can be located in grain boundaries (GBs) [30, 31], twin boundaries (TBs) [32-34] and intragranular sites [30, 32]. $M_{23} C_{6}$ most often appears in GBs where it may control the nucleation of creep cavities [30] and is often connected to intergranular corrosion due to depletion of chromium at GBs $[13,35,36]$.

$Z$ phase is a carbonitride with a distorted body centred tetragonal (BCT) structure [37-39]; it contains chromium, niobium and nitrogen. Iron may substitute for chromium and molybdenum may replace niobium [37, 38]. It is often located in GBs [38]. When the Z phase is small and evenly distributed in the matrix, it strengthens the material $[40,41]$, but if the particles grows larger it has been found to decrease the fatigue resistance [42].

$M X$-precipitates involve strong carbide and nitride formers, such as vanadium, niobium, titanium, zirconium, hafnium, and tantalum [23]. These elements are added to retard the formation of $\mathrm{M}_{23} \mathrm{C}_{6}$, resulting in less sensitisation and improving the mechanical properties, such as creep resistance [43], and corrosion resistance [44]. Some examples are: $\mathrm{Cr}_{2} \mathrm{~N}$ [45], $\mathrm{NbC}, \mathrm{NbN}$ [46], $\mathrm{Nb}(\mathrm{CN})$ [47], $\mathrm{TiC}$ [48], $\mathrm{TiN}$ [13] and $\mathrm{M}_{6} \mathrm{C}$ [49].

\section{Intermetallic phases}

$\sigma$-phase is an intermetallic phase with tetragonal structure, usually rich in iron, chromium, nickel and molybdenum [50-52], but several other compositions have been reported $[13,50]$. It can appear almost instantly at 600 ${ }^{\circ} \mathrm{C}$ [50] or after around 1000 hours ageing at $700{ }^{\circ} \mathrm{C}[53]$; the difference is attributed to the formation of carbides consuming $\sigma$-forming elements [50]. 
It is most often located in GBs $[13,50,52,54]$, but can also be found intragranularly $[13,54]$. The $\sigma$ phase is brittle at room temperature and has significantly higher hardness than the austenitic matrix, about five times higher [52]. It affects the creep resistance; large precipitates have a negative influence $[55,56]$, whereas small and evenly distributed particles might increase the creep resistance [54]. The $\sigma$-phase influences the corrosion resistance negatively by depletion of chromium and molybdenum from the matrix $[13,50]$.

Laves phase has a hexagonal structure, it consists mostly of iron, molybdenum, an intermediate content of chromium and nickel $[51,53,57]$ and a small amount of manganese, silicon, titanium and niobium [53]. It precipitates at intragranular sites and occasionally at GBs, often in small amounts, after 1000 hours ageing at temperatures between $600{ }^{\circ} \mathrm{C}$ and $800{ }^{\circ} \mathrm{C}[51,53$, $57]$.

$X$-phase has a body centred cubic (BCC) structure, it is rich in iron, chromium and molybdenum $[13,57]$. It forms at GBs and intragranularly, where it nucleate on dislocations, after 5000 hours at temperatures between $700{ }^{\circ} \mathrm{C}$ and $850^{\circ} \mathrm{C}[51,53]$. Generally, it has a negative affect on the material properties $[51,53]$.

$G$ phase is a silicide with FCC structure [58], it contains mainly nickel, silicon, and titanium. Nickel and titanium can be replaced by, for instance, chromium, iron, molybdenum, manganese and niobium $[58,59]$. The composition depends on the ageing temperature and varies with ageing time for a fixed temperature [60]. It precipitates at GBs after less than 10 hours at temperatures between $700^{\circ} \mathrm{C}$ and $800^{\circ} \mathrm{C}$ and after longer time as intragranular precipitates [13].

\subsection{Nickel-based alloys}

Nickel-based alloys are widely used in high-temperature applications at temperatures between $650^{\circ} \mathrm{C}$ and $1100^{\circ} \mathrm{C}$ since nickel is stable in the FCC structure from room temperature up to the melting temperature. Nickel-based alloys possess great corrosion resistance, strength, creep and fatigue properties at elevated temperatures. Nickel-based alloys have an austenitic matrix, called $\gamma[16,61]$.

\subsubsection{Main alloying elements in nickel-based alloys}

Nickel-based alloys consist of many alloying elements, but most of the nickelbased alloys have 10-20 wt.\% chromium, up to $8 \mathrm{wt} . \%$ aluminium and tita- 
nium, 5-10 wt.\% cobalt and small amounts of boron, zirconium and carbon. Optional common additives are molybdenum, tungsten and tantalum. The chromium content is enough to create a corrosion protective chromium oxide layer; at higher temperatures, a corrosion protective aluminium oxide layer is formed $[16,61]$.

\subsubsection{Precipitation of nickel-based alloys}

An important precipitate in nickel-based alloys is the $\gamma^{\prime}[16,62,63]$. It is a hardening precipitate that may improve the mechanical properties at elevated temperatures due to an ordered FCC structure. $\gamma^{\prime}$ Often contains nickel, aluminium and titanium [16]. Carbides and nitrides that often form are: $M_{23} C_{6}, M_{6} C[16,62-65]$ and $\operatorname{TiN}[65]$. 


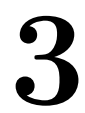

\section{Microstructural mechanisms and phenomena}

In this chapter the main microstructural mechanisms and phenomena related to the included papers are presented. 


\subsection{Deformation mechanisms}

The main plastic deformation mechanisms in the investigated austenitic alloys can be divided into two types: dislocation movement and twin controlled deformations. Since they influence the mechanical behaviour in different ways, a review of these mechanisms is provided.

\subsubsection{Dislocation movement}

A dislocation is a lattice line defect and can be divided into two different basic types: edge and screw dislocations. Edge dislocations have the Burgers vector oriented normal to the dislocation line and screw dislocations has the Burgers vector parallel to the dislocation line. Unlike edge dislocations, screw dislocations don't have a unique slip plane but rather several potential slip planes. Thus, the screw dislocation possesses greater mobility than the edge dislocation $[66,67]$.

There are two basic types of dislocation movement that may generate plastic deformation: glide and climb movement. Glide occurs when the dislocation moves in the plane containing the dislocation line and the Burgers vector and climb occurs when the dislocation moves out of the plane perpendicular to the Burgers vector. When many dislocations glide in the same slip plane, it results in planar slip which is a common plastic deformation mechanism in austenitic alloys treated in this thesis [66, 68, 69]. If there is a great number of slip steps on closely spaced parallel slip planes, slip bands will be formed [66, 70, 71]; this is also common in the investigated alloys [72, 73]. Screw dislocations can change from one slip plane to another, this is called cross-slip. If many screw dislocations cross-slip, it results in wavy slip [6668]. The stacking-fault energy (SFE) influences the cross-slip mechanism. When the SFE is low, cross-slip is restricted so that barriers to dislocation movement remain effective to higher stress levels than in materials of higher SFE. Thus, when the SFE decreases, the slip character changes from wavy to planar mode [67]. In face-centre cubic (FCC) metals, as austenitic alloys, slip generally appears in one of the four close-packed $\{111\}$ planes and in one of the three $<110>$ directions. More than one slip system can be active, which is called multi-directional slip. Activation of slip systems in other planes is rarely observed [66, 67]. To activate a slip system, a critical shear stress is required. This shear stress, acting on a slip plane, can be calculated as

$$
\tau=\frac{F}{A} \cos \phi \cos \lambda
$$


where $\tau$ is the resolved shear stress from the force $F$ acting on the crosssection area $A, \phi$ is the angle between $F$ and the normal to the slip plane and $\lambda$ is the angle between $F$ and the slip direction. The quantity $\cos \phi \cos \lambda$ is called the Schmid factor $[66,71]$.

Dislocation climb is dependent on diffusion and is for that reason thermally activated and temperature dependent; when atoms diffuse and generating vacancies, edge dislocations are enabled to move out of their original slip plane [66].

Temperature influences the energy that has to be provided for dislocations to surmount the obstacles they encounter during slip. If the conditions are sufficient, thermal vibrations of the crystal atoms may assist the dislocation to surmount obstacles at lower values of applied stress than that required at $0 \mathrm{~K}$. Thus, an increase in temperature, or a reduction in applied strain rate, will reduce the flow stress [66].

\subsubsection{Twinning}

Twins may form through different processes. Annealing twins nucleate during thermal processes [74], transformation twins come from phase transformation and deformation twins nucleate from deformation [75-77]. This review will concentrate on the latter type.

Deformation twins are initiated by a certain shear stress, which is higher than the stress needed for growth of an existing twin. The twinning process causes a rotation of the lattice such that the atoms in the twin represent a mirror image of the atoms in the matrix material $[67,75,76]$. The angle of the boundary between matrix material and twin, called twin boundary, gets a certain value due to the mirror rotation, in austenitic alloys often $60^{\circ}[75,76]$. For FCC metals, the critical twinning stress for initiation of twins is slightly influenced by temperature and strain rate, where the critical twinning stress increases with increasing temperature and strain rate. However, SFE have a larger influence on the critical twinning stress and it increases with increasing SFE. Also the grain size influences the twinning, a larger grain gives much higher twinning density than a smaller grain [76].

Formation of each deformation twin leads to a certain shear strain. This will increase plasticity of the material if a large number of twins have been formed [75, 76, 78], which is called twinning induced plasticity (TWIP) [78]. 


\subsection{Time dependent deformation mechanisms}

Deformation at elevated temperature is often associated with time dependent deformation mechanisms such as creep and also in combination with other mechanisms as for instance fatigue. A brief introduction of creep and creep-fatigue, connected to the included Paper VII and VIII respectively, is provided.

\subsubsection{Creep}

Creep is inelastic deformation during constant stress and occurs at elevated temperatures for most metallic materials. Creep deformation is a time dependent mechanism and for most metals it can be divided in three stages, shown in Fig. 2: primary creep (I), secondary (steady-state) creep (II) and tertiary creep (III). Primary creep is characterised by a rapid increase in the creep strain rate. During the secondary creep, a steady-state is obtained as the creep strain rate becomes fairly constant. In the tertiary stage, the creep strain rate once more increases rapidly until fracture occurs [16]. For austenitic alloys in high temperature applications, such as components for power plants, a creep damage mechanism associated with cavity coalescence and intergranular cracking during tertiary creep is often responsible for failure [79-81]. It is similar to the microstructural features found in Paper VII.

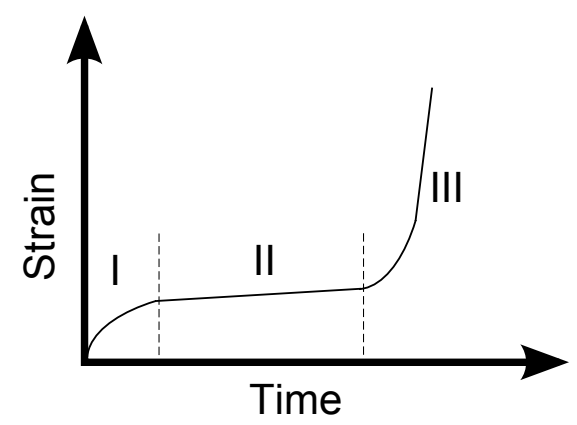

Figure 2: The three stages of creep deformation: primary (I), secondary or steady state (II) and tertiary (III) creep.

\subsubsection{Creep-fatigue interaction}

The combination of creep and fatigue leads to synergistic effects, i.e. creepfatigue interaction. The effect of dwell time during low cycle fatigue is investi- 
gated in Paper XIII for an austenitic stainless steel. The introduction of dwell time to the fatigue test caused a decrease in fatigue life [82]. Creep-fatigue life is strongly affected by grain boundary carbides since they act as favoured sites for cavity formation [82, 83]. The creep-fatigue interaction resistance is greatly influenced by the distribution, morphology and interfacial energy of carbides. For grain boundary MC carbides, the lower interfacial energy makes them less damaging compared to $\mathrm{M}_{23} \mathrm{C}_{6}$, even though they have comparable density and morphology [84]. Fine MC carbides at grain boundaries have been suggested to improve creep-fatigue resistance by preventing grain boundary sliding. Intragranular MC carbides are not desirable because they hardened the matrix, influencing the stress relaxation and thereby leading to a higher stress intensity at the crack tip [85]. It is believed that formation of cavities is related to vacancies which are generated during the tensile part of the fatigue cycle at elevated temperature. These cavities grow during the tensile dwell time as vacancies diffuse through the grain boundary [86, 87].

\subsection{Softening phenomena}

During deformation at elevated temperatures, the softening phenomena dynamic recovery (DRV) and dynamic recrystallization (DRX) may occur, both in hot working (strain rate range 1-100 $\mathrm{s}^{-1}$ ) and slow creep deformation (strain rates below $\left.10^{-5} \mathrm{~s}^{-1}\right)$. Signs of DRV and DRX appear in the stress and strain curve during flow stress and in the microstructure, see Fig. 3. Some of the investigated alloys in this thesis showed such signs of DRV and DRX, see Paper II, IV, V and VI. The phenomena affects the mechanical properties at elevated temperatures.

\subsubsection{Dynamic recovery}

DRV is influenced by dislocation density; when the flow stress increases during the first stage of deformation, due to dislocation interaction and reproduction, the rate of recovery increases with increasing dislocation density. At this stage, low angle grain boundaries (LAGB) and subgrains develop in the microstructure $[66,88]$. This process involves glide and climb of the dislocations which form LAGB. Since climb involves diffusion, a sufficient temperature for thermal activation of diffusion of point defects is needed. During DRV, some dislocation annihilation occurs. DRV can be observed in the stress-strain curve; a steady-state flow stress will be obtained due to a dynamic equilibrium between the rates of recovery and hardening $[88,89]$. 


\subsubsection{Dynamic recrystallization}

DRX may occur in alloys with low or medium SFE and initiates when a critical strain has been reached at elevated temperature. The critical strain for initiation of DRX depends not only on deformation rate and temperature, but also on chemical composition and initial grain size [66, 88-91]. During DRX, new grains originate at high angle grain boundaries but, due to the continuous deformation of the material, the dislocation density of the new grains increases. This will reduce the driving force for further growth of the new grains and eventually the growth will stop. Since DRX originates at existing high angle grain boundaries during straining, DRX may appear at boundaries as deformation bands [88]. Thus, DRX shows recrystallized grains in the microstructure, often near or at high angle grain boundaries [88, 90]; Fig. 3 shows recrystallized grains in AISI 316L after slow tensile deformation. Another sign of DRX is the decreasing flow stress in the stress-strain curve $[88,89]$.

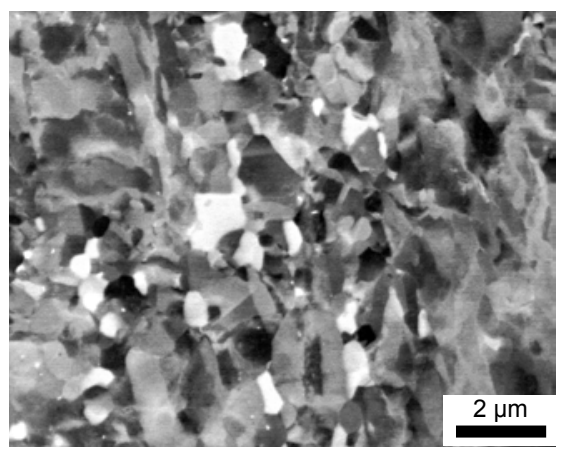

Figure 3: Electron channelling contrast image of recrystallized grain structure from DRX in slow strain rate tensile tested AISI $316 \mathrm{~L}$ at $650^{\circ} \mathrm{C}$ using a strain rate of $10^{-6} \mathrm{~s}^{-1}$.

\subsection{Dynamic strain ageing}

Dynamic strain ageing (DSA) originates from interaction between solute atoms and dislocations during plastic deformation. Under plastic flow, dislocations are gliding until they come across an obstacle where they are stationary until the obstacles are surmounted. When the dislocations are stationary, solute atoms can diffuse towards the dislocations which result in an increase 
in the activation energy for further slip and consequently also an increase in the stress needed for overcoming the obstacle [92-97]. Thus, DSA is directly influenced by the deformation rate that affects the mobility of the dislocations and the temperature that influences the diffusion rate of solute atoms. At temperatures below $350^{\circ} \mathrm{C}$ carbon is responsible for DSA while nitrogen and/or substitutional chromium atoms are responsible at higher temperatures $\left(400^{\circ} \mathrm{C}\right.$ to $\left.650^{\circ} \mathrm{C}\right)[27,73]$. It has been reported that mechanical properties, like strength and ductility, may be significantly changed due to DSA $[73,98]$. DSA is characterized by serrated yielding in the stressstrain curve, denoted as Portevin-Le Châtelier (PLC) effect or jerky flow. DSA can also lead to an increase in flow stress, work hardening rate and, most important, a negative strain rate sensitivity [99, 100]. DSA influence on ductility depends on the alloy composition [69, 99].

The PLC effect is caused by the pinning and unpinning of dislocations and is recognized by serrated yielding in stress-strain curves [69, 101-103]. There are different types of PLC effects designated A-D [69, 101, 103]. Type A is considered as locking serrations, they abruptly rise and then drop to a stress level below the general level. Type B is characterized by small oscillations around the general level of the curve. Type $\mathrm{C}$ leads to unlocking serration which is when the curve abrupt drops below the general stress level. Type D is characterized by plateaus on the curve [103]. Serrated yielding may also come from other mechanisms, e.g. twinning $[67,76]$.

\subsection{Oxidation}

For biomass-fired power plants, oxidation is one of the main concerns due to high temperatures and corrosive environment [4, 11, 104, 105]. Austenitic stainless steels exhibit good oxidation resistance at elevated temperatures in dry air due to the formation of a protective chromium-rich $\mathrm{Cr}_{2} \mathrm{O}_{3}$ or $(\mathrm{Cr}, \mathrm{Fe})_{2} \mathrm{O}_{3}$ scale [106]. The protectiveness of the chromium-rich oxide scale is decreased when adding water vapour to the atmosphere at temperatures above $600{ }^{\circ} \mathrm{C}[15,107-115]$. This because the water vapour reacts with the chromium-rich oxide which eventually causes chromium depletion due to vaporization and non-protective breakaway oxides [15, 106-115].

Thermal cycling with the addition of water vapour accelerates the onset of breakaway oxidation $[116,117]$. The formation of non-protective breakaway oxides and the protectiveness of the chromium-rich oxide depend on the ratio between the chromium depletion and the supply of chromium by diffusion from the alloy $[108,111,113,118]$. There are different approaches to improve the supply of chromium to the protective scale; increased chromium 
content is a common solution $[109,116,119]$. Another possible solution is grain refinement at the surface, using, for instance, nanocrystalline coatings $[113,117]$ or plastic deformation techniques [120] to improve the supply of chromium to the protective oxide scale. The grain refinement produces a large number of grain boundaries that increase the diffusion of chromium to the surface [121-123]. 


\section{4 \\ Experimental methods}

In this chapter, the used experimental and analysis methods are presented. The slow strain rate tensile testing, the creep-fatigue interaction tests, the insitu tensile tests and thermal cycling in water vapour environment were performed at Linköping University (LiU). The long term ageing, impact toughness testing and the conventional tensile tests were performed at AB Sandvik Materials Technology (SMT) in Sandviken, Sweden. The microscopy analyses have mainly been performed at LiU. The Grazing incidence X-ray diffraction was performed at the Department of Physics on LiU and will not be covered in this chapter. 


\subsection{Material}

All tested materials, except Haynes 282, have been supplied by SMT. All the tested materials were solution heat treated according to table 1 . Haynes 282 was also heat treated by using a two stage stabilizing and ageing treatment at $1010^{\circ} \mathrm{C}$ for 2 hours and $788^{\circ} \mathrm{C}$ for 8 hours. Five austenitic stainless steels (AISI 304, AISI 310, AISI 316L, Sandvik Sanicro ${ }^{T M} 25$ (Sanicro 25) and Sandvik Sanicro ${ }^{T M} 28$ (Sanicro 28)) and three nickel-based alloys (Alloy 617, Alloy $800 \mathrm{HT}$ and Haynes 282) have been used in the conducted experiments. The nominal chemical composition in wt.\% for each alloy is presented in table 2. After a second investigation of the aluminium content in Alloy 617, it was found that it should be 0.94 wt.\% and not 0.0094 wt.\% as stated in Paper $I V$ and $V$. This make the precipitation of $\gamma^{\prime}$ in Paper I, II and $I V$ possible. The precipitation of $\gamma^{\prime}$ has been found in Alloy 617 in an investigation not yet published, see Fig. 4. These commercial heat resistant austenitic alloys represent a range of materials from relatively low alloyed stainless steels (e.g. AISI 304) to nickel-based superalloys (e.g. Haynes 282) and the fairly new group of relatively high alloyed stainless steels (e.g. Sanicro 25).
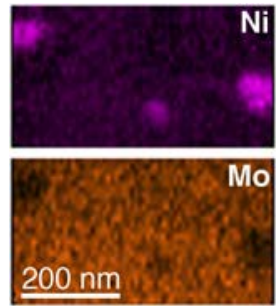
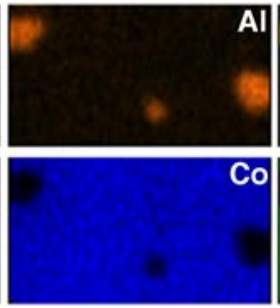
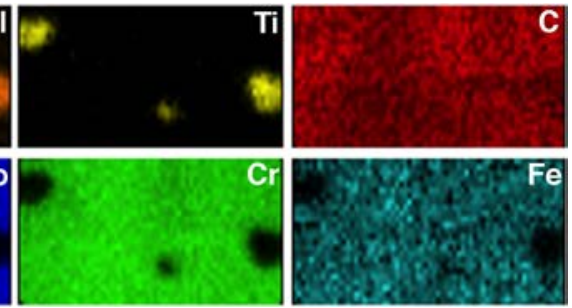

Figure 4: Chemical composition maps of $\gamma^{\prime}$ precipitates in Alloy 617, after 10 000 hours ageing at $700{ }^{\circ} \mathrm{C}$, using a transmission electron microscopy energydispersive system. Courtesy of Magnus Hörnqvist Colliander.

\subsection{Ageing}

The long term ageing used in Paper I, was performed at $650{ }^{\circ} \mathrm{C}$ and 700 ${ }^{\circ} \mathrm{C}$ for 1000, 3000 and 10000 hours in laboratory air on already machined specimens (details about the specimens are given in Section 4.3). The ageing used in Paper II, was performed at $700{ }^{\circ} \mathrm{C}$ for 500 hours in laboratory air on already machined specimens (details about the specimens are given in Section 4.4). 
CHAPTER 4. EXPERIMENTAL METHODS
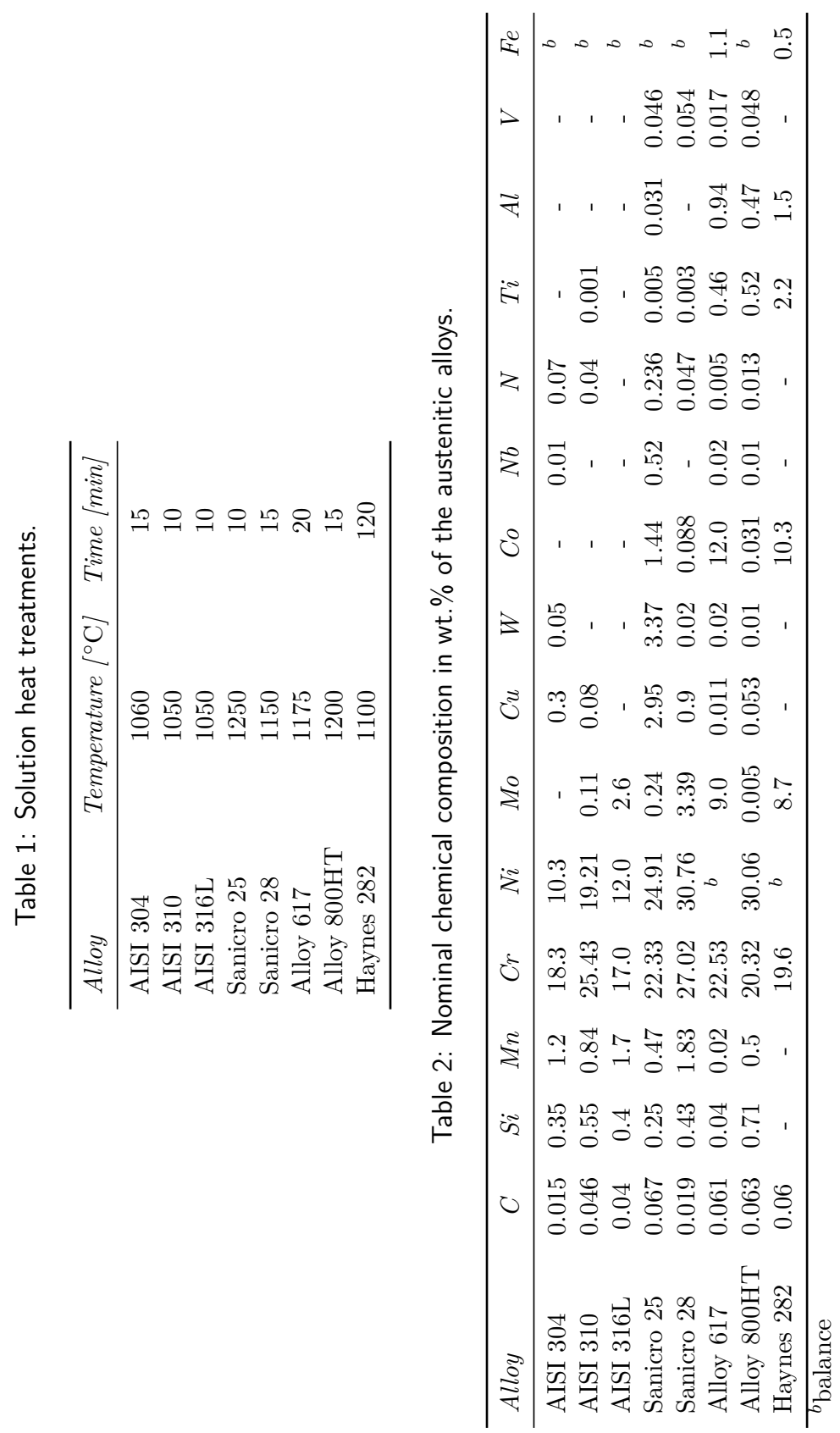


\subsection{Impact toughness testing}

The impact toughness tests were performed using the Charpy V method according to ISO 14556 standard [124]. Samples with a dimension of 10x10x55mm and V-type were used. The specimens were aged before the impact toughness tests in accordance with Section 4.2. The impact toughness testing was performed at room temperature. Two to three specimens from each ageing condition and non-aged specimens were tested.

\subsection{Tensile deformation}

Several uniaxial tensile tests have been performed within this project. Different conditions, such as different temperatures and strain rates, have been used. From tensile testing, many mechanical properties can be obtained, e.g. yield strength, tensile strength, elongation to fracture, etc. For the tensile testing performed according to EN 10 002-1 standard [125], a RoellKorthaus and an Instron 5982 tensile test machine were used, the later is shown in Fig. 5. The machines were equipped with an MTS 653 furnace and a Magtec PMA-12/2/VV7-1 extensometer and an Instron SF16 furnace and an Instron $7361 \mathrm{C}$ extensometer respectively, both used in laboratory air. For the tensile tests, round-bar specimens with a diameter of $5 \mathrm{~mm}$ and a gauge length of $50 \mathrm{~mm}$ were used.

Tensile testing was used in several of the appended papers (Paper II-VII) where strain rates from $10^{-2} \mathrm{~s}^{-1}$ down to $10^{-6} \mathrm{~s}^{-1}$ and temperatures at $23^{\circ} \mathrm{C}$ (referred to as room temperature (RT)), $300{ }^{\circ} \mathrm{C}, 400{ }^{\circ} \mathrm{C}, 500{ }^{\circ} \mathrm{C}, 600{ }^{\circ} \mathrm{C}, 650$ ${ }^{\circ} \mathrm{C}$ and $700{ }^{\circ} \mathrm{C}$ were used.

The slow strain rate tensile testing (SSRT) was performed on the Instron 5982 electromechanical tensile test machine showed in Fig. 5.

The in-situ tensile testing was performed inside a HITACHI SU-70 FEGSEM scanning electron microscope (SEM) using a specially designed Gatan microtest tensile test stage; Fig. 6 (a) shows the stage that is tilted $70^{\circ}$ for optimal diffraction. The miniature tensile stage can produce a force of maximum $5 \mathrm{kN}$. A small specimen showed in Fig. 6 (b) was used. The thickness of the specimens were ground down to less than $1 \mathrm{~mm}$, then further preparation of one side of the specimen to enable the use of electron backscatter diffraction (EBSD). The procedure is described in detail under section 4.7.2. 


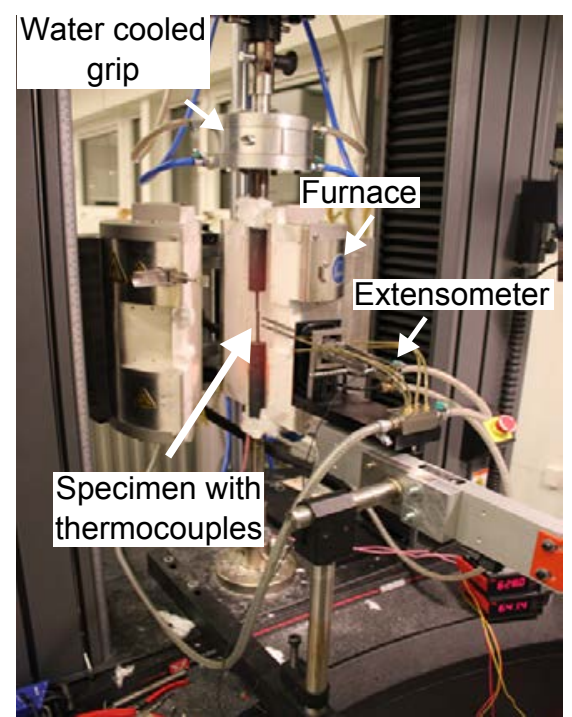

Figure 5: Electromechanical tensile test machine used for SSRT equipped with furnace, extensometer and water cooled grip.

(a)

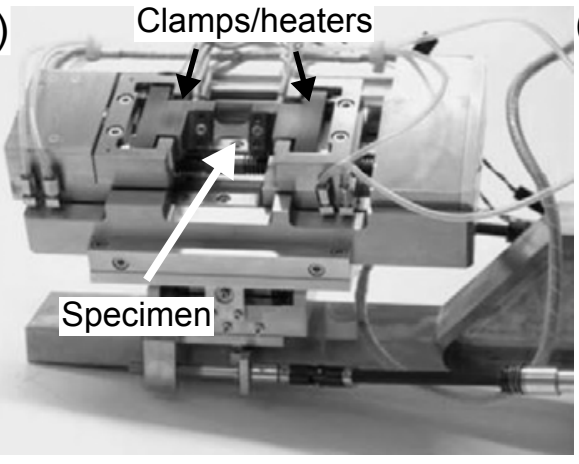

(b)

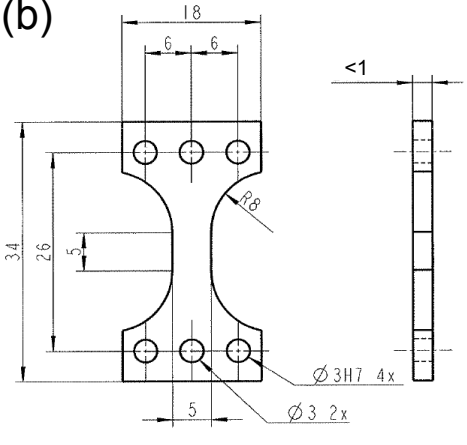

Figure 6: Miniature tensile test stage (a) and a drawing of the small specimen used for in-situ tensile test (b). 


\subsection{Creep-fatigue interaction testing}

The creep-fatigue interaction tests in Paper VIII were conducted according to ASTM E2714-13 standard [126], using an MTS servo hydraulic test machine equipped with an Instron 8800 control system, an Instron 2632-055 extensometer and an MTS 652.01 furnace. All tests were performed in strain control at two different strain ranges; $1 \%$ and $2 \%$. The testing was performed at $700{ }^{\circ} \mathrm{C}$ and three dwell times, 0, 10 and 30 minutes, were applied at maximum strain in tension and compression, shown in Fig. 7.

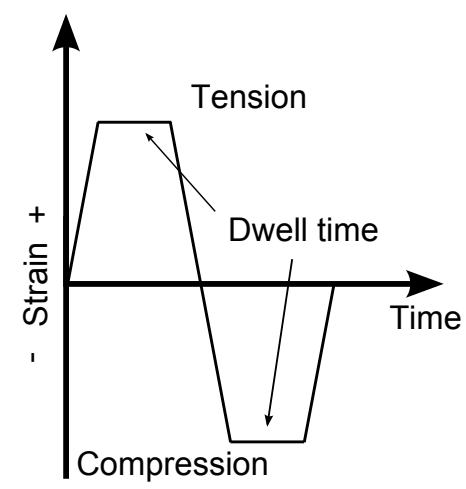

Figure 7: A schematic illustration of loading sequence during a creep-fatigue interaction test.

\subsection{Thermal cycling in water vapour environment}

Thermal cyclic testing in a corrosive environment from Paper IX was performed at $650{ }^{\circ} \mathrm{C}$ in a thermal cyclic rig, shown in Fig. 8. The specimens rested on a stationary ceramic table and the thermal cycling was accomplished by lowering and rising a furnace over the specimens. Since the specimens rested on the ceramic table, five sides of the specimen were fully exposed to the corrosive medium. Consequently, all analyses were made on the surface facing upwards. One thermal cycle consisted of a 96 hour dwell time at $650{ }^{\circ} \mathrm{C}$ followed by natural cooling until the specimens reached $100{ }^{\circ} \mathrm{C}$ which took approximately 18 minutes. The specimens were subjected to $2,5,10$ and 20 thermal cycles.

During the hot part of the cycle, water was introduced as an air-water mist which was sprayed into the furnace (not directly onto the specimens). 
The water mist immediately evaporated as it was sprayed into the furnace and increased the water vapour content in the furnace chamber. The amount of water vapour was controlled by the water-to-air ratio in the water mist and was adjusted to $\sim 15 \mathrm{~mol} \%$. This was achieved by controlling the water inlet flow into the air stream. Since the furnace was not airtight, a new burst of air-water mist was injected every 3rd minute which evaporated and flushed the furnace through with water vapour.

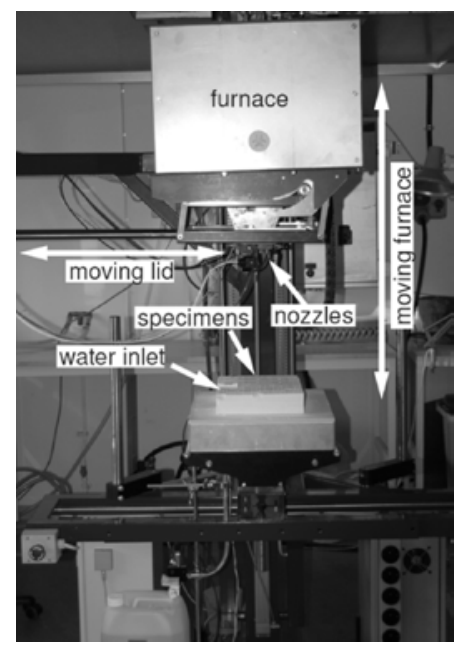

Figure 8: Cyclic corrosion rig. Courtesy of Robert Eriksson.

\subsection{Microscopy}

\subsubsection{Scanning electron microscopy}

The microstructural investigations were performed using different SEM related techniques like electron channelling contrast imaging (ECCI), electron backscatter diffraction (EBSD), energy-dispersive spectroscopy (EDS) and wave-dispersive spectroscopy (WDS).

To capture deformation, damage and even dislocation and twin structures in the highly deformed alloys, the ECCI technique was used [127-131]. In 1967, Coates [132] reported that the intensity of backscattered electrons is strongly dependent on crystal orientation in the scanning electron microscope. The same year, Booker et al. [133] suggested that the effect could be 
used to image crystal defects near the surface of a bulk specimen using a SEM, since close to the Bragg condition, the backscattered electron intensity varies rapidly with orientation. This forms the basis of the technique now called ECCI. Thus, ECCI uses the interaction between backscattered electrons and the crystal planes to generate contrast resulting in an image where local misorientation, defects and strain fields are shown as contrast variations [128136]. Fig. 9 shows the sample position perpendicular to the incident electron beam in the ECCI set up. Gutierrez-Urrutia et al. [128] studied dislocation structures and deformation twins using the ECCI and EBSD techniques in a SEM and bright-field transmission electron microscopy of the same area in a tensile deformed TWIP steel. They found that ECCI could image dislocation cell structures and mechanical twins of $30 \mathrm{~nm}$ thickness. Thus, ECCI is a powerful tool in characterizing highly deformed alloys. Fig. 10 shows dislocation structures and deformation as a plastic zone in front of a crack tip and slip bands in an austenitic alloy, using the ECCI technique. Moreover, the acceleration voltage influences the contrast in ECCI micrographs, where decreasing acceleration voltage improves the contrast. According to Gutierrez-Urrutia et al. [128] there are two main possible reasons for this. Firstly, the backscatter yield increases with decreasing acceleration voltage, which cause parts with higher intensity to appear brighter while parts with low intensity remain dark. Secondly, the interaction volume decreases with decreasing acceleration voltage, the lattice strain shows smaller variations in a smaller volume, thus diffraction conditions and contrast are better defined. ECCI investigations were performed on a HITACHI SU-70 field emission gun (FEG)-SEM and a Zeiss XB 1540 FEG-SEM, both equipped with a solid state 4-quadrant backscattered electron (BSE) detector, using $10 \mathrm{kV}$ acceleration voltage and working distances between $5 \mathrm{~mm}$ and $7 \mathrm{~mm}[128,129,137]$.

The EBSD technique provides information about phases and crystallographic orientation using Kikuchi patterns. As a simple analogy, the grains in a polycrystalline alloy act as a mirror reflecting its orientation to the observers camera. Determination of characteristic crystallographic parameters such as crystal plane spacing and angles between planes, allows the phases to be identified. Crystallographic orientations are determined by identification of the Kikuchi pattern [137-139]. To use EBSD, the specimen has to be tilted around $70^{\circ}$ against the incident electron beam to provide the optimal diffraction $[137,139]$. EBSD can be used to evaluate plastic deformation, because the degree of deformation or damage can be expressed as local crystal reorientations of grains [139-141]. Also, the grain average misorientation (GAM) has a linear relationship with plastic strain [139, 141]. Information about active slip systems in the microstructure can be provided by the EBSD technique, using obtained Euler angles and Equation 1 in sec- 


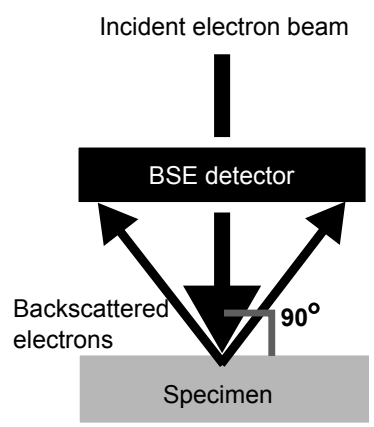

Figure 9: $\mathrm{ECCl}$ set up with the incident electron beam $90^{\circ}$ angled to the specimen, based on Gutierrez-Urrutia et al. [128].
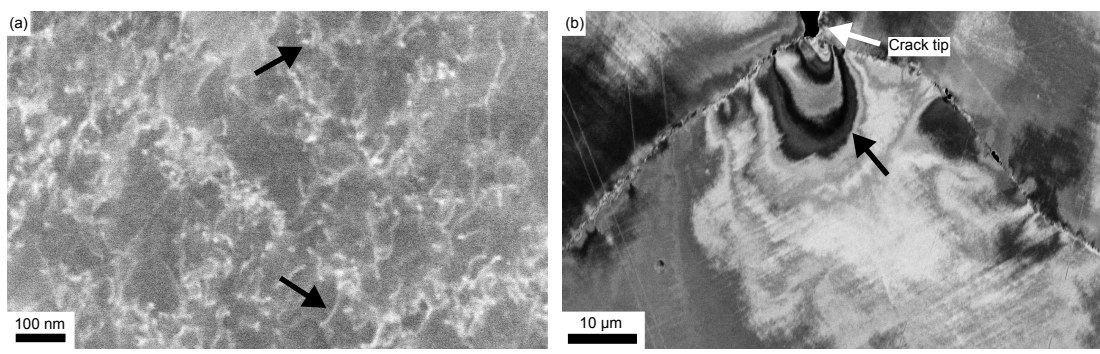

Figure 10: Dislocations and dislocation ends in Sanicro 25 (a) and plastic zone in front of a crack tip, slip bands and local strain concentrations at grain boundaries in Alloy 617 (b). 
tion 3.1.1 [142]. EBSD investigations were performed in a HITACHI SU-70 FEG-SEM equipped with an OXFORD EBSD detector and a $6500 \mathrm{~F}$ JEOL FEG-SEM equipped with a TSL OIM EBSD system, both EBSD systems used the HKL software CHANNEL 5. The EBSD-maps were measured at $15 \mathrm{kV}$ and $20 \mathrm{kV}$ acceleration voltage using a working distance of $12 \mathrm{~mm}$ up to $25 \mathrm{~mm}$ and step sizes of $0,1 \mu \mathrm{m}$ up to $4 \mu \mathrm{m}[137,139]$.

The EDS and WDS techniques provide chemical composition information of the specimen [137]. It is mainly used to collect information about precipitation during the ageing and oxidation during the thermal cycling. The EDS and WDS investigations were performed using a HITACHI SU-70 FEG-SEM and some additional EDS measurements were performed using a $6500 \mathrm{~F}$ JEOL FEG-SEM. EDS and WDS were performed at $20 \mathrm{kV}$ acceleration voltage and a working distance of $15 \mathrm{~mm}$.

\subsubsection{Specimen preparation}

To enable the use of ECCI and EBSD, a careful specimen preparation must be performed. Both techniques are surface sensitive due to scattering of the backscattered electrons. Thus, it is crucial to minimize the surface roughness before the microscopy. Both electrolyte and mechanical polishing can accomplish the critical surface preparation, in this project only the later one has been used according to the following steps:

1. $500 \mathrm{SiC}$-paper $(30 \mu \mathrm{m}), 2 \mathrm{~min}$

2. 1200 SiC-paper $(15 \mu \mathrm{m}), 2$ min

3. $4000 \mathrm{SiC}$-paper $(5 \mu \mathrm{m}), 3 \mathrm{~min}$

4. Silk cloth, diamond suspensions $(3 \mu \mathrm{m}), 5 \mathrm{~min}$

5. Woven wool cloth, diamond suspensions $(1 \mu \mathrm{m})$, lubricant, $10 \mathrm{~min}$

6. Rayon-viscose fibres cloth, diamond suspensions $(0,25 \mu \mathrm{m})$, lubricant, $15 \mathrm{~min}$

7. Neoprene foam cloth, colloidal silica suspension $(0,04 \mu \mathrm{m}), 5 \mathrm{~min}$

8. Neoprene foam cloth, water, $1 \mathrm{~min}$

After each step, specimens and holder were cleaned carefully using water and ethanol for step 1-2, and water + detergent, ethanol and ultrasonic cleaning for step 3-9. 


\section{Review of appended papers}

This Chapter provides a review of the nine appended papers. The papers are presented in regards of their content and how they are interconnected with the aims of the PhD thesis. The connections between the papers and the aims are illustrated in Fig. 1 in Chapter 1. 


\section{Paper I}

Long term high-temperature environmental effect on impact toughness in austenitic alloys

The present investigation treats the influence of precipitation and growth of precipitates due to high-temperature environment on impact toughness, for different chemical compositions.

When ageing for 10000 hours at temperatures of $650{ }^{\circ} \mathrm{C}$ and $700{ }^{\circ} \mathrm{C}$, the precipitation of intermetallic phases is detrimental for the impact toughness performance of AISI 304, Sanicro 28 and Alloy 617. Both the austenitic stainless steels suffer greatly from embrittlement due to brittle $\sigma$-phase which constitutes a large part of the microstructure. Alloy 617 is affected by niobium and molybdenum rich precipitates that cause crack initiation at grain boundaries, but seems to also gain good impact toughness from small evenly distributed precipitates.

\section{Paper II}

\section{Damage and Fracture Behaviours in Aged Austenitic Materials During High-Temperature Slow Strain Rate Testing}

The aim of this study was to investigate damage and fracture mechanisms of austenitic materials (the austenitic stainless steel AISI 304 and the nickelbased alloy Alloy 617) during uniaxial SSRT at RT and elevated temperature after long term ageing at high temperature. The role of precipitation from high-temperature ageing and the slow deformation process was evaluated by microscopy and coupled to the damage and fracture behaviour.

The investigation showed that SSRT caused intergranular cracking in both high-temperature long term aged AISI 304 and Alloy 617 at both RT and $700{ }^{\circ} \mathrm{C}$ when using a strain rate of $10^{-6} \mathrm{~s}^{-1}$. At RT the fracture is caused by cracks initiating due to stress concentration at precipitates from the ageing process in grain boundaries for both alloys. Alloy 617 also exhibits crack initiation and propagation by slip band interaction with small grain boundary precipitates. At $700{ }^{\circ} \mathrm{C}$ the fracture is caused by grain boundary precipitates formed during both the ageing process and the tensile deformation. Elongation to fracture decreases for both the aged stainless steel and the aged nickel-based alloy when a lower strain rate is used compared to a higher strain rate at $700{ }^{\circ} \mathrm{C}$. 


\title{
Paper III
}

\author{
Advanced Microstructure Studies of an Austenitic Material Us- \\ ing EBSD in Elevated Temperature In-Situ Tensile Testing in \\ SEM
}

In this study in-situ tensile testing was performed on Sanicro 25 at two different temperatures. An investigation of the influence of temperature on the deformation behaviour was performed using EBSD technique. The fracture behaviour was also discussed.

The analysis from in-situ tensile tests at RT and $300{ }^{\circ} \mathrm{C}$ in a SEM together with EBSD for Sanicro 25 shows that larger grains tend to accumulate more local plastic strain for the same macroscopic strain values at both temperatures. Somewhat higher plastic strains can be obtained at RT compared to elevated temperature for the same macroscopic strain value. Cracks initiate and propagate along the slip system(s) with the highest Schmid factor at RT.

\section{Paper IV}

Mechanical behaviours of Alloy 617 with varied strain rates at high temperatures

This study focuses on the deformation and damage mechanisms in Alloy 617 deformed using low strain rates (down to $10^{-6} \mathrm{~S}^{-1}$ ) at elevated temperatures $\left(650{ }^{\circ} \mathrm{C}\right.$ and $700{ }^{\circ} \mathrm{C}$ ) by uniaxial SSRT as well as microstructure evaluation using scanning electron microscopy techniques such as ECCI.

DSA can occur in Alloy 617 at temperatures between $650{ }^{\circ} \mathrm{C}$ and 700 ${ }^{\circ} \mathrm{C}$ with strain rate from $10^{-2} \mathrm{~s}^{-1}$ down to $10^{-6} \mathrm{~s}^{-1}$. TWIP is one of the mechanisms for a high elongation during DSA. Both strength and elongation increase with decreasing strain rate down to $10^{-4} \mathrm{~S}^{-1}$, and then both decrease with further decrease in strain rate. Micro and nano DRX can occur during the tensile deformation with very low strain rates. Repeated DRX can lead to the formation of damage in the material. 


\section{Paper V}

Deformation behaviour in advanced heat resistant materials during slow strain rate testing at elevated temperature

The current study focuses on damage and fracture micro-mechanisms related to low strain rate and high-temperature in two austenitic materials. Using uniaxial SSRT at high-temperatures $\left(650{ }^{\circ} \mathrm{C}\right.$ and $\left.700{ }^{\circ} \mathrm{C}\right)$, the influence of low strain rates on these mechanisms could be investigated. Also precipitation due to high-temperature and deformation could be coupled to the damage and fracture behaviours.

The dominant damage micro-mechanisms in Alloy 617, at all tested conditions, is interaction between slip bands and grain boundaries, causing strain concentrations. At all the tested temperatures, when using strain rates down to $10^{-3} \mathrm{~s}^{-1}$, the dominant fracture micro-mechanisms are cracked particles or cracks between particle and matrix. When lower strain rates are used at elevated temperature, small cracks in the grain boundaries, due to the embrittlement from precipitates, becomes the dominant fracture micro-mechanism. At RT, near the fracture surface, AISI 316L has a microstructure that is heavily deformed from multi-directional slip bands and planar slip interacting with grain boundaries causing damage as strain concentrations. At elevated temperatures, when using a slow strain rate $\left(10^{-6} \mathrm{~S}^{-1}\right)$, AISI $316 \mathrm{~L}$ also shows the same fracture micro-mechanism as Alloy 617, which means small cracks appear in the grain boundaries due to embrittlement from precipitates.

\section{Paper VI}

Characterisation of austenitic stainless steels deformed at elevated temperature

This study focuses on the deformation mechanisms at elevated temperatures for three commercial austenitic stainless steels and two commercial nickelbased alloys. The alloys were characterised in terms of microstructure, mechanical properties and stress-strain response. The alloys cover a range from relatively low alloyed austenitic stainless steel (e.g. AISI 316L) to nickelbased alloys (e.g. Alloy 617) and the interesting area between austenitic stainless steels and nickel-based alloys consisting of the advanced, highly alloyed, heat resistant austenitic stainless steel Sanicro 25. The different austenitic alloys were tested by uniaxial tensile testing at different elevated temperatures from $400{ }^{\circ} \mathrm{C}$ up to $700{ }^{\circ} \mathrm{C}$. Their stress-strain response was 
analysed and the deformation mechanisms were characterised by scanning electron microscopy.

The investigated materials show planar dislocation driven deformation at elevated temperature and deformation twinning is an active deformation mechanism even at elevated temperatures up to $700{ }^{\circ} \mathrm{C}$ in austenitic stainless steels. Different influence of temperature on ductility was observed, where a better high-temperature ductility is governed by a higher amount of nickel and solid solution hardening elements.

\section{Paper VII}

\section{Characterisation of creep deformation during slow strain rate tensile testing}

The strain rate dependent deformation of the superalloy Haynes 282 during SSRT at $700{ }^{\circ} \mathrm{C}$ has been characterised using constitutive modelling and microscopy. The model is based on the kinematic hardening rule combined with the Norton equation. The microstructure development was characterised and related to the influence of both strain rate dependent and independent deformation, using ECCI. The mechanical tests were performed using five different strain rates from $10^{-2} \mathrm{~s}^{-1}$ to $10^{-6} \mathrm{~s}^{-1}$.

The constitutive model simulate the experimental results with good agreement. From microstructure investigations, clear evidence of damage and cracking, similar to creep damage in Haynes 282 is observed. Therefore, it is concluded that the strain rate dependent deformation during SSRT should be considered as creep.

\section{Paper VIII}

Creep and fatigue interaction behavior in Sanicro 25 heat resistant austenitic stainless steel

This paper provides a study on the creep-fatigue interaction of Sanicro 25 at $700{ }^{\circ} \mathrm{C}$. The influence of dwell time on the cyclic deformation behaviour and life is evaluated. ECCI technique is used to characterise the influence of dwell time on cyclic plastic deformation, precipitation behaviour and recovery phenomena in the microstructure.

The results show that the introduction of dwell time causes a larger plastic strain range. The results also show that dwell time gives a shorter life 
at a lower strain range, but has no or small effect on the life at a higher strain range. Fracture investigation shows that dwell time results in more intergranular cracking.

\section{Paper IX}

Surface phase transformation in austenitic stainless steel induced by cyclic oxidation in humidified air

The purpose of the present study is to investigate the formation of $\alpha^{\prime}$ martensite at the surface of an AISI 304 stainless steel during thermal cycling in water vapour environment. The influence of cyclic oxidation on formation of $\alpha^{\prime}$ martensite is discussed using thermodynamical simulations. The effect of the $\alpha^{\prime}$ martensite on corrosion is also discussed.

Four main oxide types are formed, they are most likely: (1) outer $\mathrm{Fe}_{2} \mathrm{O}_{3}$ or an iron-rich $(\mathrm{Fe}, \mathrm{Cr})_{2} \mathrm{O}_{3},(2)$ at the metal surface there is a chromium-rich $(\mathrm{Cr}, \mathrm{Fe})_{2} \mathrm{O}_{3}$, (3) inward growing oxides are presumably nickel-rich $(\mathrm{Cr}, \mathrm{Fe}$, $\mathrm{Ni})_{3} \mathrm{O}_{4}$ and (4) nickel-poor $(\mathrm{Cr}, \mathrm{Fe}, \mathrm{Ni})_{3} \mathrm{O}_{4}$ spinel oxide. $\alpha$ ' Martensite forms during cooling from $650{ }^{\circ} \mathrm{C}$ to $100{ }^{\circ} \mathrm{C}$. This is due to chromium depletion caused by oxidation at the surface which locally rises the $M_{s}$ temperature. The $\alpha^{\prime}$ martensite grows thicker with increasing numbers of cycles during the thermal cycling. The $\alpha^{\prime}$ martensite transforms back to FCC at 650 ${ }^{\circ} \mathrm{C}$ during the thermal cycling. The formation of $\alpha$ ' martensite will give several smaller grains at the surface compared to the grains in the FCC matrix. Even though the $\alpha^{\prime}$ martensite transforms back to $\mathrm{FCC}$ at $650{ }^{\circ} \mathrm{C}$, the increased number of grain boundaries will improve the chromium diffusion within this region. A more chromium-rich protective scale is formed above the $\alpha^{\prime}$ martensite layer compared to regions where no $\alpha^{\prime}$ martensite layer rapidly formed. For this reason, areas that lack the $\alpha^{\prime}$ martensite are more consumed by inward corrosion and the outer oxide scale is thicker than at the areas with $\alpha^{\prime}$ martensite. Thus, the formation of $\alpha^{\prime}$ martensite is locally decreasing the in- and outward scale growth. 


\section{Conclusions}

In this chapter, the conclusions from the conducted research within this PhD thesis, related to the aims stated in Chapter 1, are presented. 
Tougher operation conditions, to achieve increased efficiency of biomassfired power plants and move towards more sustainable power production, will push austenitic stainless steels above the limit of there present design. Deeper understanding of the high-temperature behaviour of austenitic alloys is required to improve the performance of austenitic stainless steels through material development. The focus of this $\mathrm{PhD}$ thesis is the influence of long term high-temperature ageing on mechanical properties (aim 1); the influence of very slow deformation rates at high-temperature on deformation, damage and fracture (aim 2); and the influence of high-temperature environment and cyclic operation conditions on material behaviour (aim 3). By providing further understanding on these topics, it is believed that this $\mathrm{PhD}$ thesis can contribute to the material development of improved, advanced heat resistant austenitic stainless steels. By doing so, this $\mathrm{PhD}$ thesis may also contribute to the general goals of KME (see Chapter 1) and long term benefits for industry and society overall.

During long term high-temperature ageing (up to 10000 hours at $650{ }^{\circ} \mathrm{C}$ and $700{ }^{\circ} \mathrm{C}$ ) it was found that the precipitation and growth of precipitates strongly influence the impact toughness depending on the chemical composition of the alloy. In the tested austenitic stainless steels (AISI 304 and Sanicro 28), the intermetallic $\sigma$-phase constitutes an increasing part of the microstructure with increasing time and temperature. The $\sigma$-phase is brittle at room temperature and becomes detrimental for the impact toughness, especially when it has a needle shape. It was also found that the tested nickel-based alloy (Alloy 617) possesses a better structural integrity and has an impact toughness less influenced by long term ageing at elevated temperatures. (Contributing to aim 1)

The dominant deformation mechanisms during uni-axial tensile testing at elevated temperatures and moderate strain rates are dislocation driven planar slip and localised slip bands in one or multi-directions as well as deformation twinning. When the strain rate is decreased, these deformation mechanisms are accompanied by time dependent deformation and recovery mechanisms such as dynamic recovery and dynamic recrystallisation. The typical damage mechanisms during slow strain rate tensile testing at elevated temperatures are strain concentrations and micro-cracks at grain boundaries due to interaction between deformation and precipitates. The predominant damage mechanism of the time dependent deformation is cavities at grain boundaries. Fracture occurs mainly intergranularly due to grain boundary embrittlement from precipitates and coalescence of micro-cracks. (Contributing to aim 2)

The creep-fatigue interaction behaviour of an austenitic stainless steel (Sani- 
cro 25) shows that dwell time causes a larger plastic strain range. The results also show that dwell time gives shorter life at a lower strain range, but has none or small effect on the life at a higher strain range. Thermal cyclic testing in a water vapour environment of an austenitic stainless steel (AISI 304) shows the effects of detrimental chromium vaporisation, causing both outward oxide growth of a non-protective iron rich oxide and inward oxide scale growth of spinel oxides, consuming the bulk material. It was also found that formation of $\alpha^{\prime}$ martensite, related to thermal martensitic transformation, influence the oxidation by decreasing the oxide growth. This is attributed to increased chromium supply from the bulk material by grain boundary diffusion due to the formation of small $\alpha^{\prime}$ martensite grains that increase the number of grain boundaries at the surface. (Contributing to aim 3) 



\section{Outlook}

This chapter gives an outlook of further research that can be performed based on this PhD thesis. 
Within the work that underlies this $\mathrm{PhD}$ thesis, several different mechanical tests have been performed at elevated temperatures. In the research field of material used for biomass-fired power plants, much focus is on oxidation and corrosion since they are the most crucial limitations of the materials used today. However, the influence of both mechanical and thermal stresses can not be overlooked; mechanisms such as creep and fatigue as well as structural integrity for long term service is important. Therefore, more effective test methods, closer to real operation conditions with interaction of chemical and mechanical material behaviour, are needed. Well designed, more effective and realistic methods can be used as tools for material development, directly by the industry and/or for advanced material modelling. By performing mechanical tests in an high-temperature environment, involving the environment found in biomass combustors, this could be achieved. Already existing methods for high-temperature material property evaluation, such as thermomechanical fatigue, creep-fatigue interaction and slow strain rate tensile testing, could, by adding a biomass-fired related environment, provide this more realistic testing.

Another future step would be to identify and investigate material phenomena that could be devastating for further material development towards more efficient power production, such as stress relaxation cracking that occur in some heat resistant austenitic alloys and are detrimental for the use of the alloy. 


\section{Bibliography}

[1] A.K.M. Sadrul Islama and M. Ahiduzzaman. Biomass energy: Sustainable solution for greenhouse gas emission. AIP Conference Proceedings, 1440:23-32, 2012.

[2] K.A. Al-attab and Z.A. Zainal. Externally fired gas turbine technology: A review. Applied Energy, 138:474-487, 2015.

[3] C. Cambero and T. Sowlati. Assessment and optimization of forest biomass supply chains from economic, social and environmental perspectives - A review of literature. Renewable and Sustainable Energy Reviews, 36:62-73, 2014.

[4] R. Saidur, E.A. Abdelaziz, A. Demirbas, M.S. Hossain, and S. Mekhilef. A review on biomass as a fuel for boilers. Renewable and Sustainable Energy Reviews, 15:2262-2289, 2011.

[5] Hassan Khodaei, Yasir M. Al-Abdeli, Ferdinando Guzzomi, and Guan H. Yeoh. An overview of processes and considerations in the modelling of fixed-bed biomass combustion. Energy, 88:946 - 972, 2015.

[6] L. Trygg and S. Amiri. European perspective on absorption cooling in a combined heat and power system - A case study of energy utility and industries in sweden. Applied Energy, 84:1319-1337, 2007.

[7] N.L. Panwar, S.C. Kaushik, and S. Kothari. Role of renewable energy sources in environmental protection: A review. Renewable and Sustainable Energy Reviews, 15:1513-1524, 2011.

[8] J. Yin and Z. Wu. Corrosion behavior of TP316L of superheater in biomass boiler with simulated atmosphere and deposit. Chinese Journal of Chemical Engineering, 17:849-853, 2009. 
[9] R. Viswanathan and W. Bakker. Materials for ultrasupercritical coal power plants - boiler materials: Part 1. Journal of Materials Engineering and Performance, 10:81-95, 2001.

[10] A. Phongphiphat, C. Ryu, Y. B. Yang, K. N. Finney, A. Leyland, V. N. Sharifi, and J. Swithenbank. Investigation into high-temperature corrosion in a large-scale municipal waste-to-energy plant. Corrosion Science, 52:3861-3872, 2010.

[11] P. Viklund, A. Hjörnhede, P. Henderson, A. Stålenheim, and R. Pettersson. Corrosion of superheater materials in a waste-to-energy plant. Fuel Processing Technology, 105:106-112, 2013.

[12] J. Pettersson, H. Asteman, J.-E. Svensson, and L.-G. Johansson. KCl induced corrosion of a 304-type austenitic stainless steel at $600{ }^{\circ} \mathrm{C}$; The role of potassium. Oxidation of Metals, 64:23-41, 2005.

[13] T. Sourmail. Precipitation in creep resistant austenitic stainless steels. Materials Science and Technology, 17:1-14, 2001.

[14] Kristin Dietrich, Jesus M Latorre, Luis Olmos, and Andres Ramos. The Role of Flexible Demands in Smart Energy Systems. Springer Berlin Heidelberg, 2013.

[15] H. Asteman, J.-E. Svensson, and L.-G. Johansson. Oxidation of 310 steel in $\mathrm{H}_{2} \mathrm{O} / \mathrm{O}_{2}$ mixtures at $600{ }^{\circ} \mathrm{C}$ : The effect of water-vapourenhanced chromium evaporation. Corrosion Science, 44:2635-2649, 2002 .

[16] R. C. Reed. The Superalloys Fundamentals and Applications. Cambridge University Press, 2008.

[17] M. Calmunger. Effect of temperature on mechanical response of austenitic materials. Master's thesis, Linköping University, 2011.

[18] KME homepage. http://www.elforsk.se/programomraden/elvarme/kme/, Accessed: 2015-10-27.

[19] Mattias Calmunger. High-temperature behaviour of austenitic alloysinfluence of temperature and strain rate on mechanical properties and microstructural development, 2013. Linköping University.

[20] J. R. Davis, editor. Stainless Steels. ASM International, 2004. 
[21] G. Krauss. STEELS Processing, Structure, and Performance. ASM International, 2005.

[22] F.B. Pickering. Physical mettallurgical developments of stainless steels. Stainless Steels, 84:2-28, 1985.

[23] K.H. Lo, C.H. Shek, and J.K.L. Lai. Recent developments in stainless steels. Materials Science and Engineering: R: Reports, 65:39-104, 2009.

[24] V. Vodárek. Creep behavior and microstructural evolution in AISI $316 \mathrm{LN}+\mathrm{Nb}$ steels at $650{ }^{\circ} \mathrm{C}$. Materials Science and Engineering A, 528:4232-4238, 2011.

[25] J. W. Simmons. Overview: High-nitrogen alloying of stainless steels. Materials Science and Engineering A, 207:159-169, 1996.

[26] H.J McQueen and N.D Ryan. Constitutive analysis in hot working. Materials Science and Engineering: A, 322:43-63, 2002.

[27] G. V. P. Reddy, R. Sandhya, K. B. S. Rao, and S. Sankaran. Influence of nitrogen alloying on dynamic strain ageing regimes in low cycle fatigue of AISI 316LN stainless steel. Procedia Engineering, 2:2181-2188, 2010 .

[28] S. Lu, Q.-M. Hub, B. Johansson, and L. Vitos. Stacking fault energies of $\mathrm{Mn}, \mathrm{Co}$ and $\mathrm{Nb}$ alloyed austenitic stainless steels. Acta Materialia, 59:5728-5734, 2011.

[29] L. Vitos, J.-O. Nilsson, and B. Johansson. Alloying effects on the stacking fault energy in austenitic stainless steels from first-principles theory. Acta Materialia, 54:3821-3826, 2006.

[30] T.L. Burnett, R. Geurts, H. Jazaeri, S.M. Northover, S.A. McDonald, S.J. Haigh, P.J. Bouchard, and P.J. Withers. Multiscale 3D analysis of creep cavities in AISI type 316 stainless steel. Materials Science and Technology (United Kingdom), 31:522-534, 2015.

[31] M.H. Lewis and B. Hattersley. Precipitation of $\mathrm{M}_{23} \mathrm{C}_{6}$ in austenitic steels. Acta Metallurgica, 13:1159-1168, 1965.

[32] F.R. Beckitt and B.R. Clark. The shape and mechanism of formation of $\mathrm{M}_{23} \mathrm{C}_{6}$ carbide in austenite. Acta Metallurgica, 15:113-129, 1967. 
[33] L.K. Singhal and J.W. Martin. The growth of $\mathrm{M}_{23} \mathrm{C}_{6}$ carbide on incoherent twin boundaries in austenite. Acta Metallurgica, 15:1603-1610, 1967.

[34] B. Sasmal. Formation of lamellar $\mathrm{M}_{23} \mathrm{C}_{6}$ on and near twin boundaries in austenitic stainless steels. Bulletin of Materials Science, 6:617-623, 1984 .

[35] M. Matula, L. Hyspecka, M. Svoboda, V. Vodárek, C. Dagbert, J. Galland, Z. Stonawska, and L. Tuma. Intergranular corrosion of AISI 316L steel. Materials Characterization, 46:203-210, 2001.

[36] T. Fukunaga, K. Kaneko, R. Kawano, K. Ueda, K. Yamada, N. Nakada, M. Kikuchi, J.S. Barnard, and P.A. Midgley. Formation of intergranular $\mathrm{M}_{23} \mathrm{C}_{6}$ in sensitized type-347 stainless steel. ISIJ International, 54:148-152, 2014.

[37] D.H. Jack and K.H. Jack. Structure of Z-Phase, NbCrN. J Iron Steel Inst (London), 210:790-792, 1972.

[38] C. Örnhagen, J.-O. Nilsson, and H. Vannevik. Characterization of a nitrogen-rich austenitic stainless steel used for osteosynthesis devices. Journal of Biomedical Materials Research, 31:97-103, 1996.

[39] J. Erneman, M. Schwind, P. Liu, J.-O. Nilsson, H.-O. Andrén, and J. Ågren. Precipitation reactions caused by nitrogen uptake during service at high temperatures of a niobium stabilised austenitic stainless steel. Acta Materialia, 52(14):4337-4350, 2004.

[40] E.J. Giordani, A.M. Jorge Jr., and O. Balancin. Proportion of recovery and recrystallization during interpass times at high temperatures on a $\mathrm{Nb}$ - and $\mathrm{N}$-bearing austenitic stainless steel biomaterial. Scripta Materialia, 55(8):743 - 746, 2006.

[41] M.C. Mataya, C.A. Perkins, S.W. Thompson, and D.K. Matlock. Flow stress and microstructural evolution during hot working of alloy $22 \mathrm{Cr}-$ $13 \mathrm{Ni}-5 \mathrm{Mn}-0.3 \mathrm{~N}$ austenitic stainless steel. Metallurgical and Materials Transactions A: Physical Metallurgy and Materials Science, 27:12511266, 1996.

[42] E.J. Giordani, V.A. Guimarães, T.B. Pinto, and I. Ferreira. Effect of precipitates on the corrosion-fatigue crack initiation of ISO 5832-9 stainless steel biomaterial. International Journal of Fatigue, 26:11291136, 2004. 
[43] K.S. Min and S.W. Nam. Correlation between characteristics of grain boundary carbides and creep-fatigue properties in AISI 321 stainless steel. Journal of Nuclear Materials, 322:91-97, 2003.

[44] V. Moura, A.Y. Kina, S.S.M. Tavares, L.D. Lima, and F.B. Mainier. Influence of stabilization heat treatments on microstructure, hardness and intergranular corrosion resistance of the AISI 321 stainless steel. Journal of Materials Science, 43:536-540, 2008.

[45] J.W. Simmons. Influence of nitride $\left(\mathrm{Cr}_{2} \mathrm{~N}\right)$ precipitation on the plastic flow behavior of high-nitrogen austenitic stainless steel. Scripta Metallurgica et Materiala, 32:265-270, 1995.

[46] J. Källqvist and H.-O. Andrén. Microanalysis of a stabilised austenitic stainless steel after long term ageing. Materials Science and Engineering A, 270:27-32, 1999.

[47] Y.-J. Oh, B.J. Lee, O. Yoo, B.S. Lee, and J.H. Hong. Precipitation behavior of carbonitrides in type 347 stainless steels with various $\mathrm{C}$ and $\mathrm{N}$ contents. Metallurgical and Materials Transactions A: Physical Metallurgy and Materials Science, 33:1565-1569, 2002.

[48] T. Thorvaldsson and G.L. Dunlop. Precipitation reactions in Tistabilized austenitic stainless steel. Metal science, 14:513-518, 1980.

[49] L.P. Stoter. Thermal ageing effects in AISI type 316 stainless steel. Journal of Materials Science, 16:1039-1051, 1981.

[50] M. Schwind, J. Källqvist, J.-O. Nilsson, J. Ågren, and H.-O. Andrén. $\sigma$-Phase precipitation in stabilized austenitic stainless steels. Acta Materialia, 48:2473-2481, 2000.

[51] J.K.L. Lai. A study of precipitation in AISI type 316 stainless steel. Materials Science and Engineering, 58:195-209, 1983.

[52] T. Ohmura, K. Tsuzaki, K. Sawada, and K. Kimura. Inhomogeneous nano-mechanical properties in the multi-phase microstructure of longterm aged type 316 stainless steel. Journal of Materials Research, 21: 1229-1236, 2006.

[53] Y. Minami, H. Kimura, and Y. Ihara. Microstructural changes in austenitic stainless steels during long-term aging. Materials Science and Technology, 2:795-806, 1986. 
[54] D.J. Li, Y. Gao, J.L. Tan, F.G. Wang, and J.S. Zhang. Effect of $\sigma$-phase on the creep properties of Cr25Ni20 stainless steel. Scripta Metallurgica, 23:1319-1321, 1989.

[55] J.K. Lai and A. Wickens. Microstructural changes and variations in creep ductility of 3 casts of type 316 stainless steel. Acta Metallurgica, $27: 217-230,1979$.

[56] C.J. McMahon Jr. On the mechanisms of creep damage in type 316 stainless steel. Scripta Metallurgica, 19:733-737, 1985.

[57] Y. Yang, L. Tan, and J.T. Busby. Thermal stability of intermetallic phases in Fe-rich $\mathrm{Fe}-\mathrm{Cr}-\mathrm{Ni}-\mathrm{Mo}$ alloys. Metallurgical and Materials Transactions A: Physical Metallurgy and Materials Science, 46:39003908, 2015.

[58] M.K. Miller and J. Bentley. APFIM and AEM investigation of CF8 and CF8M primary coolant pipe steels. Materials Science and Technology, 6:285-292, 1990.

[59] J.M. Vitek. G-phase formation in aged type 308 stainless steel. Metallurgical transactions. A, Physical metallurgy and materials science, 18 A:154-156, 1987.

[60] T.R. Leax, S.S. Brenner, and J.A. Spitznagel. Atom probe examination of thermally ages CF8M cast stainless steel. Metallurgical Transactions A, 23(10):2725-2736, 1992.

[61] C. T. Sims, N. S. Stoloff, and W. C. Hagel, editors. Superalloys II. John Wiley \& sons, 1987.

[62] M. Speicher, A. Klenk, K. Maile, and E. Roos. Behaviour of Ni-based alloys for fossil-fired power plant components in the long-term creep regime. Advanced Materials Research, 278:241-246, 2011.

[63] L. M. Pike. Superalloy 2008, chapter Development of a fabricable gamma-prime $\left(\gamma^{\prime}\right)$ strengthened superalloy, pages 191-200. TMS, 2008.

[64] K. Mo, G. Lovicu, H.-M. Tung, X. Chen, and J.F. Stubbins. High temperature aging and corrosion study on alloy 617 and alloy 230 . Journal of Engineering for Gas Turbines and Power, 133:052908-1-, 2011. 
[65] S. Rahman, G. Priyadarshan, K.S. Raja, C. Nesbitt, and M. Misra. Investigation of the secondary phases of alloy 617 by scanning kelvin probe force microscope. Materials Letters, 62:2263-2266, 2008.

[66] D. Hull and D. J. Bacon. Introduction to Dislocations. ButterworthHeinmann, 2007.

[67] R. W. Hertzberg. Deformation and Fracture Mechanics of Engineering Materials. John Wiley \& sons, 1995.

[68] V. Gerold and H.P. Karnthaler. On the origin of planar slip in f.c.c. alloys. Acta Metallurgica, 37:2177-2183, 1989.

[69] I. Nikulin and R. Kaibyshev. Deformation behavior and the PortevinLe Chatelier effect in a modified $18 \mathrm{Cr}-8 \mathrm{~N}$ stainless steel. Materials Science and Engineering A, 528:1340-1347, 2011.

[70] J. C. Fisher, E. W. Hart, and R. H. Pry. Theory of slip-band formation. Phys. Rev., 87:958-961, 1952.

[71] P. Villechaise, L. Sabatier, and J. C. Girard. On slip band features and crack initiation in fatigued 316L austenitic stainless steel: Part 1: Analysis by electron back-scattered diffraction and atomic force microscopy. Materials Science and Engineering: A, 323:377-385, 2002.

[72] H. Mughrabi and H.-J. Christ. Cyclic deformation and fatigue of selected ferritic and austenitic steels: Specific aspects. ISIJ International, 37(12):1154-1169, 1997.

[73] S.-G. Hong and S.-B. Lee. Mechanism of dynamic strain aging and characterization of its effect on the low-cycle fatigue behavior in type 316L stainless steel. Journal of Nuclear Materials, 340:307-314, 2005.

[74] Y. Jin, M. Bernacki, G.S. Rohrer, A.D. Rollett, B. Lin, and N. Bozzolo. Formation of annealing twins during recrystallization and grain growth in 304L austenitic stainless steel. Materials Science Forum, 753:113116, 2013.

[75] J. W. Christian and S. Mahajan. Deformation twinning. Progress in Materials Science, 39:1-157, 1995.

[76] M. A. Meyers, O. Vhringer, and V. A. Lubarda. The onset of twinning in metals: A constitutive description. Acta Materialia, 49:4025-4039, 2001. 
[77] F. K. Yan, G. Z. Liu, N .R. Tao, and K. Lu. Strength and ductility of $316 \mathrm{~L}$ austenitic stainless steel strengthened by nano-scale twin bundles. Acta Materialia, 60:1059-1071, 2012.

[78] O. Grässel, L. Krüger, G. Frommeyer, and L. W. Meyer. High strength Fe-Mn-(Al, Si) TRIP/TWIP steels development - properties - application. International Journal of Plasticity, 16:1391-1409, 2000.

[79] B. Michel. Formulation of a new intergranular creep damage model for austenitic stainless steels. Nuclear Engineering and Design, 227: 161-174, 2004

[80] T. Lillo, J. Cole, M. Frary, and S. Schlegel. Influence of grain boundary character on creep void formation in alloy 617. Metallurgical and Materials Transactions A: Physical Metallurgy and Materials Science, 40:2803-2811, 2009.

[81] C. J. Boehlert and S. C. Longanbach. A comparison of the microstructure and creep behavior of cold rolled HAYNES®230 alloy ${ }^{\mathrm{TM}}$ and HAYNES®282 alloy $^{\mathrm{TM}}$. Materials Science and Engineering A, 528: 4888-4898, 2011.

[82] Xiang Chen, Zhiqing Yang, Mikhail A. Sokolov, Donald L. Erdman III, Kun Mo, and James F. Stubbins. Effect of creep and oxidation on reduced fatigue life of Ni-based alloy 617 at $850{ }^{\circ} \mathrm{C}$. Journal of Nuclear Materials, 444:393-403, 2014.

[83] P.S. Maiya and S. Majumdar. Elevated-temperature low-cycle fatigue behavior of different heats of type 304 stainless steel. Metallurgical Transactions A, 8:1651-1660, 1977.

[84] Kyung Seon Min, Ki Jae Kim, and Soo Woo Nam. Investigation of the effect of the types and densities of grain boundary carbides on grain boundary cavitation resistance of AISI 321 stainless steel under creep-fatigue interaction. Journal of Alloys and Compounds, 370:223229, 2004 .

[85] N. Fujita, H.K.D.H. Bhadeshia, and M. Kikuchi. Modeling $\mathrm{M}_{6} \mathrm{C}$ precipitation in niobium-alloyed ferritic stainless steel. Metallurgical and Materials Transactions A: Physical Metallurgy and Materials Science, 33:3339-3347, 2002. 
[86] Soo Woo Nam. Assessment of damage and life prediction of austenitic stainless steel under high temperature creep-fatigue interaction condition. Materials Science and Engineering: A, 322:64-72, 2002.

[87] S.W. Nam, Y.C. Yoon, B.G. Choi, J.E. Min Lee, and J.W. Hong. The normalized coffin-manson plot in terms of a new damage function based on grain boundary cavitation under creep-f-atigue condition. Metallurgical and Materials Transactions A: Physical Metallurgy and Materials Science, 27:1273-1281, 1996.

[88] F. J. Humphreys and M. Hatherly. Recrystallization and Related Annealing Phenomena. Elsevier Science \& Technology Books, 1996.

[89] W. Roberts and B. Ahlblom. A nucleation criterion for dynamic recrystallization during hot working. Acta Metallurgica, 26:801-813, 1978.

[90] D. Samantaray, S. Mandal, C. Phaniraj, and A. K. Bhaduri. Flow behavior and microstructural evolution during hot deformation of AISI Type 316 L(N) austenitic stainless steel. Materials Science and Engineering A, 528:8565-8572, 2011.

[91] E. I. Poliak and J. J. Jonas. A one-parmenter approach to determining the critical conditions for the initiation of dynamic recrystallization. Acta Materialia, 44:127-136, 1996.

[92] L. H. de Almeida, I. Le May, and P. R. O. Emygdio. Mechanistic modeling of dynamic strain aging in austenitic stainless steels. Materials Characterization, 41:137-150, 1998.

[93] M. Hörnqvist and B. Karlsson. Temperature and strain rate dependence of the dynamic strain aging effect in an $\mathrm{Al}-\mathrm{Zn}-\mathrm{Mg}$ alloy. Materials Science and Technology, 22:213-222, 2006.

[94] A. Van Den Beukel. On the mechanism of serrated yielding and dynamic strain ageing. Acta Metallurgica, 28:965-969, 1980.

[95] A. W. Sleeswyk. Slow strain-hardening of ingot iron. Acta Metallurgica, 6:598-603, 1958.

[96] R. A. Mulford and U. F. Kocks. New observations on the mechanisms of dynamic strain aging and of jerky flow. Acta Metallurgica, 27:11251134,1979 . 
[97] G. V. P. Reddy, R. Sandhya, M. Valsan, and K. B. S. Rao. Temperature dependence of low cycle fatigue of $316(\mathrm{~N})$ weld metals and $316 \mathrm{~L}(\mathrm{~N}) / 316(\mathrm{~N})$ weld joints. Materials science and technology, 26: $1384-1392,2010$.

[98] S. L. Mannan, K. G. Samuel, and P. Rodriguez. Influence of temperature and grain size on the tensile ductility of AISI 316 stainless steel. Materials Science and Engineering, 68:143-149, 1985.

[99] G. Chai. IAS 2008. In Influence of nitrogen content on the static and dynamic strain ageing in super duplex stainless steels, 2008.

[100] G. R. Stewart and J. J. Jonas. Static and dynamic strain aging at high temperatures in 304 stainless steel. ISIJ International, 44:1263-1272, 2004 .

[101] W. Karlsen, M. Ivanchenko, U. Ehrnstén, Y. Yagodzinskyy, and H. Hänninen. Microstructural manifestation of dynamic strain aging in AISI 316 stainless steel. Journal of Nuclear Materials, 395:156-161, 2009 .

[102] M. C. Cai, L. S. Niu, T. Yu, H. J. Shi, and X. F. Ma. Strain rate and temperature effects on the critical strain for Portevin-Le Châtelier effect. Materials Science and Engineering A, 527:5175-5180, 2010.

[103] M. Ivanchenko. Dynamic strain aging of austenitic stainless steels and Ni-base alloys. PhD thesis, Aalto University, 2010.

[104] C. Pettersson, J. Pettersson, H. Asteman, J.-E. Svensson, and L.-G. Johansson. KCl-induced high temperature corrosion of the austenitic $\mathrm{Fe}-\mathrm{Cr}-\mathrm{Ni}$ alloys $304 \mathrm{~L}$ and Sanicro 28 at $600{ }^{\circ} \mathrm{C}$. Corrosion Science, 48:1368-1378, 2006.

[105] V.B. Trindade, U. Krupp, Ph.E.-G. Wagenhuber, and H.-J. Christ. Oxidation mechanisms of $\mathrm{Cr}$-containing steels and $\mathrm{Ni}$-base alloys at high-temperatures - Part I: The different role of alloy grain boundaries. Materials and Corrosion, 56:785-790, 2005.

[106] I. G. Wright and R. B. Dooley. A review of the oxidation behaviour of structural alloys in steam. International Materials Reviews, 55:129$167,2010$.

[107] H. Asteman, J.-E. Svensson, L.-G. Johansson, and M. Norell. Indication of chromium oxide hydroxide evaporation during oxidation of 304L 
at $873 \mathrm{~K}$ in the presence of $10 \%$ water vapor. Oxidation of Metals, 52 : 95-111, 1999.

[108] H. Asteman, J.-E. Svensson, M. Norell, and L.-G. Johansson. Influence of water vapor and flow rate on the high-temperature oxidation of 304L; Effect of chromium oxide hydroxide evaporation. Oxidation of Metals, 54:11-26, 2000.

[109] S. Henry, A. Galerie, and L. Antoni. Abnormal oxidation of stabilized ferritic stainless steels in water vapor. Materials Science Forum, 369372:353-360, 2001.

[110] A. Yamauchi, K. Kurokawa, and H. Takahashi. Evaporation of $\mathrm{Cr}_{2} \mathrm{O}_{2}$ in atmospheres containing $\mathrm{H}_{2} \mathrm{O}$. Oxidation of Metals, 59:517-527, 2003.

[111] H. Asteman, J.-E. Svensson, and L.-G. Johansson. Effect of watervapor-induced $\mathrm{Cr}$ vaporization on the oxidation of austenitic stainless steels at 700 and $900{ }^{\circ} \mathrm{C}$. Journal of The Electrochemical Society, 151: B141-B150, 2004.

[112] H. Asteman, K. Segerdahl, J.-E. Svensson, L.-G. Johansson, M. Halvarsson, and J.E. Tang. Oxidation of stainless steel in $\mathrm{H}_{2} \mathrm{O} / \mathrm{O}_{2}$ environments - Role of chromium evaporation. Materials Science Forum, 461-464:775-782, 2004.

[113] X. Peng, J. Yan, Y. Zhou, and F. Wang. Effect of grain refinement on the resistance of 304 stainless steel to breakaway oxidation in wet air. Acta Materialia, 53:5079-5088, 2005.

[114] M. Halvarsson, J.E. Tang, H. Asteman, J.-E. Svensson, and L.-G. Johansson. Microstructural investigation of the breakdown of the protective oxide scale on a 304 steel in the presence of oxygen and water vapour at $600{ }^{\circ} \mathrm{C}$. Corrosion Science, 48:2014-2035, 2006.

[115] L. Intiso, L.-G. Johansson, J.-E. Svensson, and M. Halvarsson. Oxidation of Sanicro $25(42 \mathrm{Fe} 22 \mathrm{Cr} 25 \mathrm{NiWCuNbN})$ in $\mathrm{O}_{2}$ and $\mathrm{O}_{2}+\mathrm{H}_{2} \mathrm{O}$ environments at $600-750{ }^{\circ} \mathrm{C}$. Oxidation of Metals, 83:367-391, 2015.

[116] N. K. Othman, J. Zhang, and D. J. Young. Temperature and water vapour effects on the cyclic oxidation behaviour of $\mathrm{Fe}-\mathrm{Cr}$ alloys. Corrosion Science, 52:2827-2836, 2010.

[117] J. Zhang, X. Peng, D. J. Young, and F. Wang. Nano-crystalline coating to improve cyclic oxidation resistance of 304 stainless steel. Surface $\mathscr{E}$ Coating Technology, 217:162-171, 2013. 
[118] H. Asteman, K. Segerdahl, J.-E. Svensson, and L.-G. Johansson. The influence of water vapor on the corrosion of chromia-forming steels. Materials Science Forum, 369-372:277-286, 2001.

[119] R. Peraldi and B. A. Pint. Effect of Cr and Ni contents on the oxidation behavior of ferritic and austenitic model alloys in air and water vapor. Oxidation of Metals, 61:463-483, 2004.

[120] R.K. Singh Raman and Rajeev K. Gupta. Oxidation resistance of nanocrystalline vis-á-vis microcrystalline $\mathrm{Fe}-\mathrm{Cr}$ alloys. Corrosion Science, 51:316-321, 2009.

[121] J. Horváth, R. Birringer, and H. Gleiter. Diffusion in nanocrystalline material. Solid State Communications, 62:319-322, 1987.

[122] Yu.R. Kolobov, G.P Grabovetskaya, M.B. Ivanov, A.P. Zhilyaev, and R.Z. Valiev. Grain boundary diffusion characteristics of nanostructured nickel. Scripta materialia, 44:873-878, 2001.

[123] Z.B. Wang, N.R. Tao, W.P. Tong, J. Lu, and K. Lu. Diffusion of chromium in nanocrystalline iron produced by means of surface mechanical attrition treatment. Acta Materialia, 51:4319-4329, 2003.

[124] ISO 14556: Metallic materials - Charpy V-notch pendulum impact test - Instrumented test method.

[125] EN 10 002-1: Metallic materials - Tensile testing - Part 1: Method of test at ambient temperature.

[126] E2714-13: Standard test method for creep-fatigue testing.

[127] J. J. Moverare, S. Johansson, and R. C. Reed. Deformation and damage mechanisms during thermal-mechanical fatigue of a single-crystal superalloy. Acta Materialia, 57:2266-2276, 2009.

[128] I. Gutierrez-Urrutia, S. Zaefferer, and D. Raabe. Electron channeling contrast imaging of twins and dislocations in twinning-induced plasticity steels under controlled diffraction conditions in a scanning electron microscope. Scripta Materialia, 61:737-740, 2009.

[129] S. Johansson, J. Moverare, and R. Peng. Recent applications of scanning electron microscopy [neueste anwendungen der rasterelektronenmikroskopie]. Praktische Metallographie/Practical Metallography, 50: 810-820, 2013. 
[130] I. Gutierrez-Urrutia, S. Zaefferer, and D. Raabe. Coupling of electron channeling with EBSD: Toward the quantitative characterization of deformation structures in the SEM. JOM, 65:1229-1236, 2013.

[131] S. Zaefferer and N.-N. Elhami. Theory and application of electron channelling contrast imaging under controlled diffraction conditions. Acta Materialia, 75:20-50, 2014.

[132] D. G. Coates. Kikuchi-like reflection patterns obtained with the scanning electron microscope. Philosophical Magazine, 16:1179-1184, 1967.

[133] G. R. Booker, A. M. B. Shaw, M. J. Whelan, and P. B. Hirsch. Some comments on the interpretation of the 'kikuchi-like reflection patterns' observed by scanning electron microscopy. Philosophical Magazine, 16: 1185, 1967.

[134] M. A. Crimp. Scanning electron microscopy imaging of dislocations in bulk materials, using electron channeling contrast. Microscopy Research and Technique, 69:347-381, 2006.

[135] A. J. Wilkinson and P. B. Hirsch. Electron diffraction based techniques in scanning electron microscopy of bulk materials. Micron, 28:279-308, 1997.

[136] I. Gutierrez-Urrutia and D. Raabe. Dislocation and twin substructure evolution during strain hardening of an $\mathrm{Fe}-22$ wt.\% Mn-0.6wt.\% C TWIP steel observed by electron channeling contrast imaging. Acta Materialia, 59:6449-6462, 2011.

[137] J. Goldstein, D. E. Newbury, D. C. Joy, C. E. Lyman, P. Echlin, E. Lifshin, L. Sawyer, and J. R. Michael. Scanning Electron Microscopy and X-Ray Microanalysis. Springer, 2002.

[138] O. Engler and V. Randle. Introduction to texture analysis. CRC Press Inc, 2009.

[139] J. A. Schwartz, K. Mukul, A. L. Brent, and D. P. Field. Electron Backscattering Diffraction in Material Science. Springer Science + Business Media, 2009.

[140] S. I. Wright, M. M. Nowell, and D. P. Field. A review of strain analysis using electron backscatter diffraction. Microscopy and Microanalysis, 17:316-329, 2011. 
[141] R. Yoda, T. Yokomaku, and N. Tsuji. Plastic deformation and creep damage evaluations of type 316 austenitic stainless steels by EBSD. Materials Characterization, 61:913-922, 2010.

[142] N. Jia, R. Lin Peng, G. C. Chai, S. Johansson, and Y. D. Wang. Direct experimental mapping of microscale deformation heterogeneity in duplex stainless steel. Materials Science and Engineering A, 491:425-433, 2008 . 


\section{Part II}

Papers Included 



\section{Papers}

The articles associated with this thesis have been removed for copyright reasons. For more details about these see:

http://urn.kb.se/resolve?urn=urn:nbn:se:liu:diva-122945 